Portland State University

PDXScholar

6-4-1974

\title{
Differential Measurement of a Language Concept Presented via Video Tape Playback to First Grade Students
}

Richard Warren Trullinger

Portland State University

Follow this and additional works at: https://pdxscholar.library.pdx.edu/open_access_etds

Part of the Broadcast and Video Studies Commons, and the Education Commons Let us know how access to this document benefits you.

\section{Recommended Citation}

Trullinger, Richard Warren, "Differential Measurement of a Language Concept Presented via Video Tape Playback to First Grade Students" (1974). Dissertations and Theses. Paper 2423.

https://doi.org/10.15760/etd.2420

This Thesis is brought to you for free and open access. It has been accepted for inclusion in Dissertations and Theses by an authorized administrator of PDXScholar. Please contact us if we can make this document more accessible: pdxscholar@pdx.edu. 


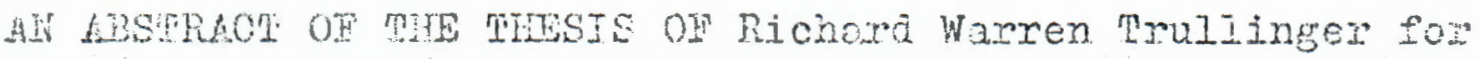
the fraster of Science in Speech: Emphasis in Speech Pathology/kudiology presented May 28, 1974.

Sitile: Jirferential Measurement of a Ianguage Concept Presented Via Video Tape PIayback to First Grade Strdentis.

ATQROVED BY WENBIRS OE THE IFESTS CONYTTRPE:

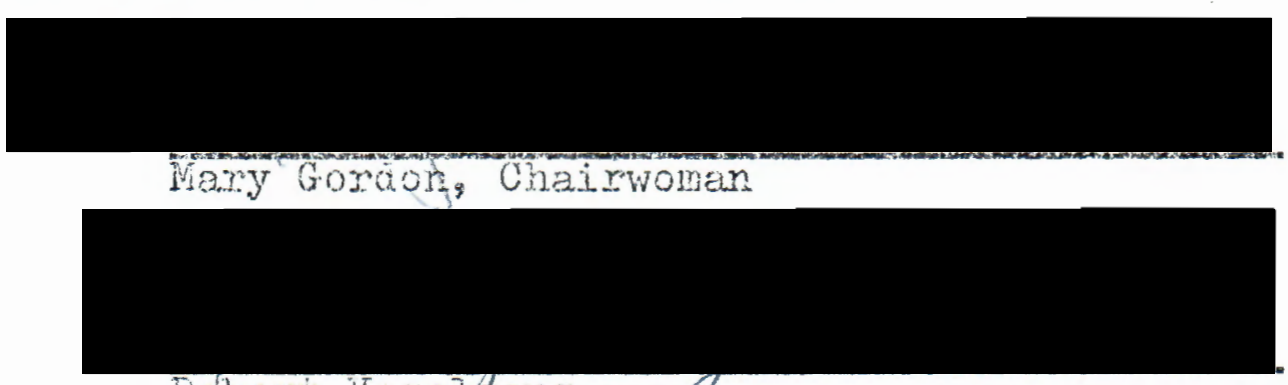

Fobert Togelfong

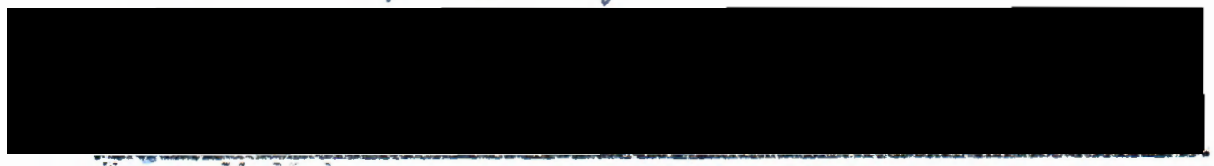

Joan Monarion

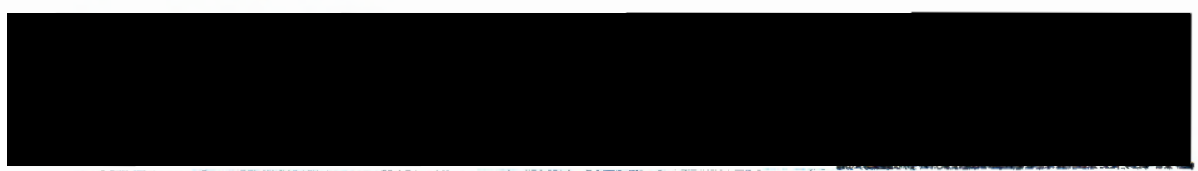

Robert Wenter

Educational television began in 1932 at the state University of Jowa. Until 1952, the potential of its corm tributions to chucation vere not fully recomized. In 1952, however, the Federal Communication Comission created noncomercial television statjons. Prom that point in time, 
eduedjonal televisior has neshroumed.

Wren chough muk has been done in the field of educotional television, reported studies with vajidated results were round to be iew. The Sesame Street evaluations apm peared to be an exception. A large amount of Iiterature describing the reaults of presenting a skill to the general population wes found. ivothing, however, was found relating to the teaching of a specific language concept to a cesignated specific group other than those studies which presented prograne to the "riasses."

This study tasted the hypothesis: At least 80 percent of a given first grade population will respond accurateiy to the post-testing of a language concept, attex the concopt has been rresented to then via a video tape playback usjug puppetxy as the teaching method. In essence, the study was aesigned to determire whether or not an individualized conoent could be presented to a specific population using the above methods and procedures, the study was iso designed to detcrmine whether a male-female difference existed in learning language concepts and whether thexe existec difierences anong socioeconomic levejs.

The subjects for this study consisted of a sample of students from six first erade classes within Portland school. District Number One, Portiland, Oregon. The examinen consisted of one speech pathology graduate student at the inater's level. The investigator administered a larguage 
concept test for debermining prom and poswosto results. From the language concepts pre-test, two corcepts, "dwelling" and "assistarce". (botil rrom tre Peabody Picture Vocabulary Test, Form $B$ ) ware chosen to be the presented concepts. Each of three different five-minuto video tape playback presentations were ther shown to the subjects on three consecutive days. A post-test, Following the three days of language intervertion, was aỉministered aiter a one day period of non-intervention.

The results indicated a very high success rate for learning the language concepts, i.e., 53.04 percent increase for "assistance" ard 97.17 percent increase for "dwelling." It was also found that no great veriations existod in increase of correct responses for males and females. Socioeconornic differences were not founa to be significant which may have been due to investigator error in choosing the school to represent each socioeconomic level. It was concluded that a specific language concept can be taught to a predetermined first grade population via video tape playback using puppetry as the teaching method.

The highly significant results may not have occurred if the study had used different methods and procedures while employing a video tape playback system. Whe results which were obtained in this study, indicated that by using the prescribed methods of puppetry, the concepts were learned in a short period of time with results which were quanticitable and valjd. 
TO PHE OFFICE OF GRADUATE STUDIES AND THSEAROE:

The members of the committee approve the thesis of Rjohard Warren Trullinger presented June 4, 1974.

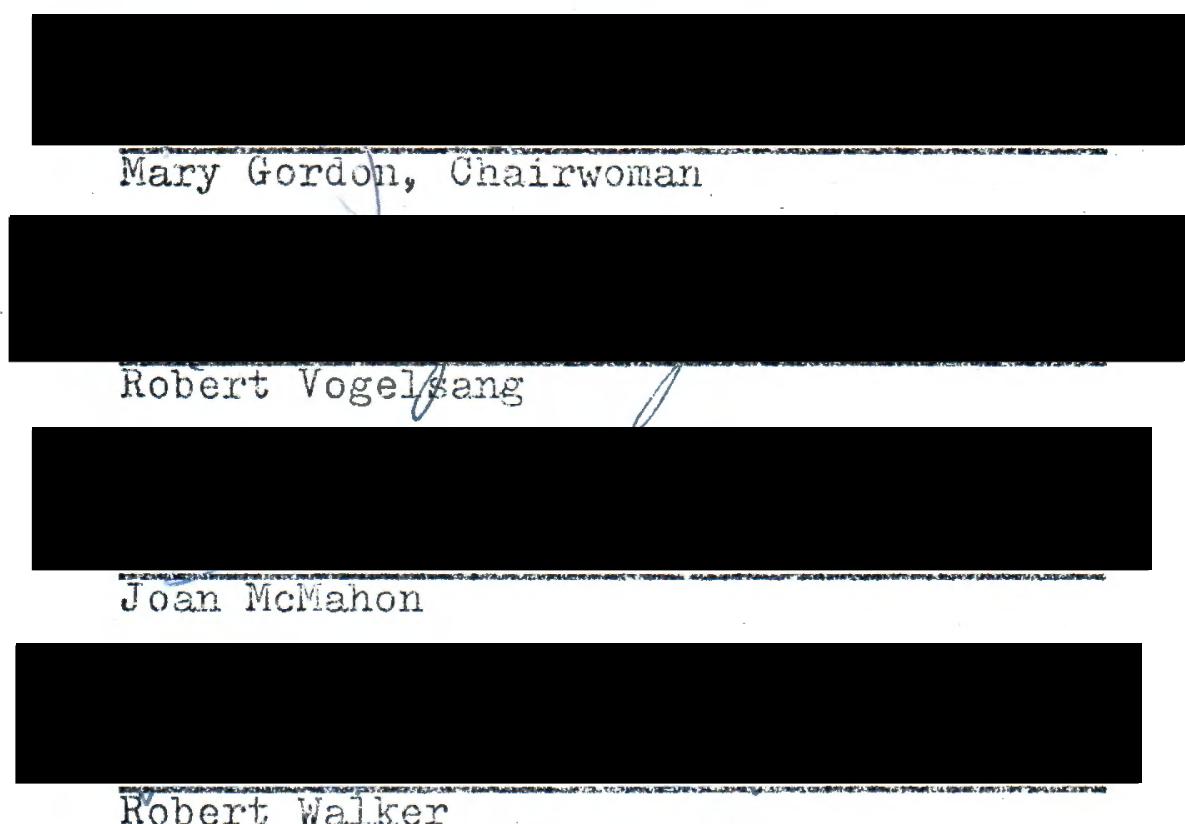

\section{APPROVED:}

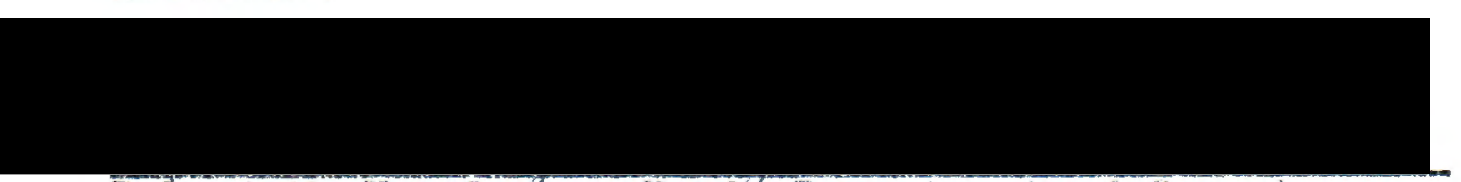

Robert h. Togeisgng, Head, Department of Speech

David H. Olark, Dean or Grákate studies and Research

June 4, 1974 


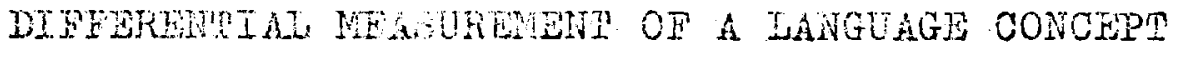 BAESENITD TA VIDEO TAIS FLAYBACK \\ MO FIRSI: GRADE STUDENTS
}

\author{
by \\ RICHARD WARREN TRUDILINGER
}

A. thesis submitted in partial fulfillment of the requirements for the degree of:

MASTER OF SCIPNCE

SPRECH: MMPHASIS IN SPTECH PATHOLOGY/AUDIOLOGY 


\section{ACKNOWLEDGNENS}

In writing a thesis of thin nature, an author is indebted to many sources. A special note of gratitude is in orden to the people who so generously provided time, knowledge, experjance, ind suggestions. These incluae the fOLIOHE:

Mary Goraion.

Thesis director

Rovert Vogelseng Committee member, puppets, and puppet stage

Joan pliahon Committee member and instigator of the original thesis idea

Dean Forbes

Subjects and liaison between Portlaro State University and the Portiand School District Number One, Area II

Ron frullinger Invaluable assistant in operating the puppets and their roices for the video and audio taping of the lessons

Rose Grubb Puppet's voices

Partiojeting teachers of Portzand School District Number one, Area II

An aditional apureciation is extended to Robert Waker and his television staf.t. They so graciously video taped the corceyt lessona, provided the equicinent needed for nonitoring whice in the schools, and placed the final product on file in thejx library for future viewing. I wish to deatcate this thesis to my wife Ialual as 
she not orit has giver me help, understanding, and reinforcerert but has been and still is my best friend. Iastiy, I wish to thank the Department of Speech, Speech ark Hearing Scienees, Portland State University, for their faith in me as a person and as a student. 
MABLE OR GOMTESE

PAGE

ACKNOWLEGMENS ................ 11i

IIST OF PABLES. . . . . ............ v vi

IIST OF FIGURHS . . . . . . . . . . . . v vili

CHAPTSR

I INRRODUCTON. ............. 1

Introdnetion. •.......... 1

Statemert oz gurpose. . . . . . . 2

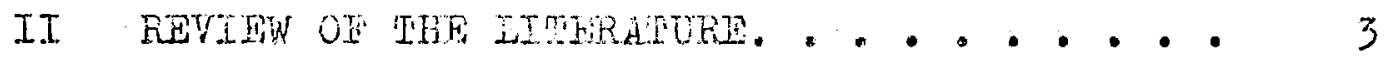

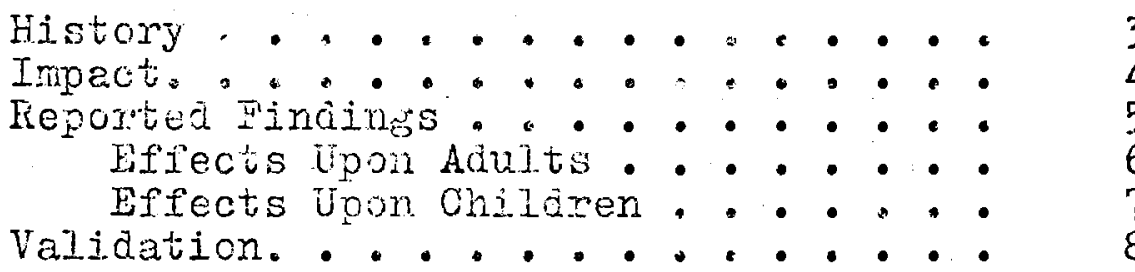

III MERHODS AND FROCEDURBS. . . . . . . 10

Subjects. ........... . 10

Examiner. . ............ 11

Instrumentation .......... 11

Production.......... 11

Playback. . . . ..... 12

Procedures. . . . ........ 13

Data Analysis . . . . . . . . 16

IV RESUITS AND DISCUSEION. • • • • • • • • 17

Results............. 17

Dverali Eludings. ....... . 17

Dweling. . . . . . . . . 18

Assistarce. . . . . . . . . 18

Corcept Not Presented ...... 19

Ratio dccording to Sexes..... 20 


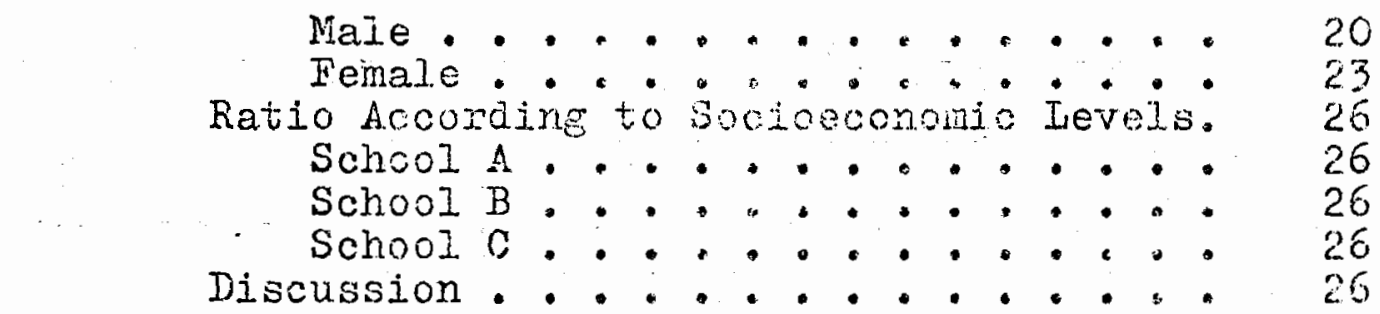

$\mathrm{V}$ SUMMARI AND INPIICAMICNS . . . . . . . 32

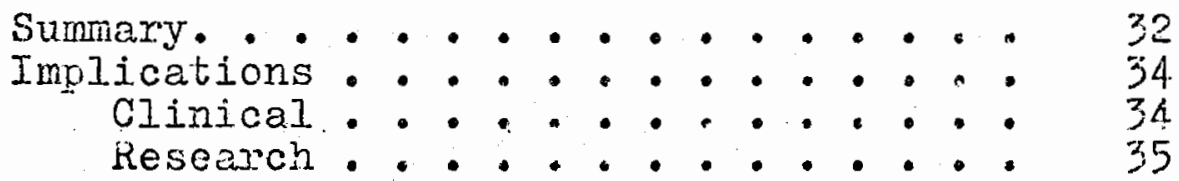

REEERENCES CITED . . . . . . . . . . . . . 37

APPEITDIX

A VIDEO TADED IESSON PRESENTIMG THIS CONCHPT OE

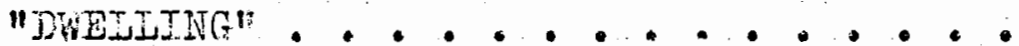

B VIDEO TAFED IESSON PRESENMING THE CONGFPT OF

"ASSISTANCE" • • . . . . . . . . . 


\section{IIST OF PABIES}

TABLE

PAGS

I. Indicators of Socioeconomic Ievels for Parm ticipating schools ........ . . .

II Success Ratio for all Schools from Premest to Post-test for the concept "Dwellirg"

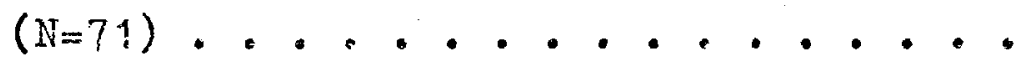

III Success Ratjo for all Schools Prom Pre-test

to Post-test for the Concept "Assistance"

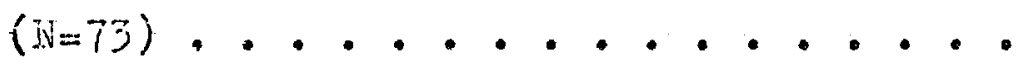

IV Male Success Ratio for all Schools from Fretest to Post-test for the Conoppt "Dwelling" $(N=42)$. . . . . . . . . .

V Male Success Ratio for all Schools from Pretest to Post-test for the Concept "Assistance" $(\mathrm{N}=42)$. . . . . . . .

VI Female Success Ratio for all Schools from

Pre-test to Post-test for the Concept

"DweLIing" ( $N=29)$. . . . . . . . .

VII Female Success Ratio for ajl Schools from

Pre-test to Post-test for the Concept

"Assistance" (N=30). . . . . . . . 


\section{IIST OF FIGURIS}

FIGURE

PABN

1. AV-3650 Sony video tape recorder with Sony

CVI-192U monitor mounted on poxtaile

viewing cart . . . . . . . . . .

2. Overall increase in correct response to the concepts based upon pre-test and posttest scores. . . ..........

3. Success ratio for concept not presented,

1.e., "Assistance"........... 20

4. Success ratio for concept not presented,

i.e., "Dwelling" . . . . . . . . .

5. Overall corroct responses indicated by

male subjects for both concepts. . .

6. Overall correct responses indicated by

fenale subjects for botn concepts. . .

7. Percentage of students within a given

school indicating "rnowledge" of the

concept presented to them via video

tape playback. . . . . . . . . .

8. Percentage of subjects demonstrating

"knowledge" of concept on pre- and

post-test. . . . . . . . . . . 


\section{CHAPTER I}

\section{INTRODUCTION}

At present, educational television is receiving nueh publicjty. National children's programs such as Segerie Street and the Electric Gompany are supplementing classroon instructional material throughout the Western Hemisphers. Estimations have indicated that no form of technology has so expeditiously ana completely been arrogated, explored, researshed, and employed by instructional personnel as has the medium of television. Xet very littie nas been dont to quantitatively validate what influence these programs have on learning of language concepts, especially in the area of inaiviaualized concepts for a specific population.

When television has been employed within the classrooin as an aid, one wonders if the equipment has been employed to no avail other than possibly as a "baby-sitting" device, or if measurable learning has occurred. Weeliver (1972), in an attempt to answer such questions, has stated little research exists which can provice a foundation for "confidert future development and decision-making." Children are culturally trained from infancy to view visual reproductions (Selden, 1971), as is evidenced by the ract that teierision reaches 97 percent of all United 
Weico howeholds and that "children are exposed to upwards of trirty hours of teletision for each week" (Palmer, 1973). It was pertinent to ask, in view of the large amount of time devoted to this activity, whether video tape playback - actually could be kised in a constructive manner, i.e., to teach with quentifiable results.

\section{Statement of Purpose}

Tre intent of this study was to examine the effectiveness of teaching a language concept transmitted by video tape playback when presented to a population of first grade stuaentis using puppetry as the teaching method. In essence, the study was concerned with whether or not an individuenized concept couja be presented to a specific population using the cibove methods and procedures.

It was nypothesized that 80 percent or more of the subjects would learn the language concept upon post-testing for that conceot. The essential question, therefore, was: What percentage of a given first grade population will learn a language concept when that concept has been presented to trem through the mediun of video tape playback using puppets as the teachixg method? Secondary questions were:
1) Do male-female differences exist in choosing correct responses?
2) Joes socioeconoric status affect response
behavior? 
GHAPRER IT

REVIEW OF THE LITSBATURE

Histogy

The history of educational television is dated back as far as 1932. In that year, the State University of Iowa produced the first formal educational television program for instructional purposes. Hull (1962), has stated that approximately 4.00 programs were transmitted from Iowa between 1932 and 1939. Course content inciuded the areas of art, shorthard, engineexing, botany, drame, and scine cultural entertainment.

By the early $1950^{\prime} \mathrm{s}$, there were 40 comnercial stations and 600,000 receivers. In spite of technical inperfections and the high cost of receivers, commercial television had captured the public's interest as no other form of media had done.

Educational television, however, had not shared this national enthusiasm. In spite of the Iowa experiment of 1932, educators had not seen the potential and had ignored the jmplications of educational television nearly completely. By 1948, crily five educational institutions in the United States were involved in television and television planring. Syracuse University offered the first 
poxal gradate program for professional training of tele. Tsion students in 1950.

In 1952, a major breakthrough for educational television occurred. As a result of the Federal Communications Combission allocation hearings, the non-commercial edlicational television station was initiated. At that time, 242 chanrels in the oroadcast band were allocated for exclusive use by educational establishments. Since then, many more channels have been approved and instituted (Hull, 1962).

\section{Impact}

The inpact television has had on children has been demonstrated in Meyer's (1973) study entitled "Children's Perceptions of Favorite Television Characters As Behavioral Models." He reiterated the known fact that children see a combination of slices of reality and fiction presented during the day through the medium of television. He also stated that the chilaren watch many of the sane television shows that their parents do. Meyer reported:

\footnotetext{
- more than 5 mizlion under the age of 12 are still watchirg at 11:00 P.M. By age 18, the typical. American child will have watched more than 20,000 hours of television. . . Despite the pervasiveness of television in reaching chiloren and occupying theix time, relatively little attention has been focused until recently on the effects of television on chilaren.
}

In rescarching effects of comnerclal television, Gross (1974) reported that for certain individuals, their 
balevision hexoes were proviaing undesirable models of beheviox. He further stated that television just does not ref]ect the "real" worla. In conjunction with this, Meyer (1973) has cominented: "They [the children] see the violent neans of conflict resolution being applied by their favorite television characters as admirable behavior worthy of imitation." Depending upon the way the medium has been used, accordirg to the recent Surgeon General's report, television can have a beneficial or harmful impact (Meyer, 1973).

\section{Reported Findings}

Within the framework of non-commercialized television, the types of programs which have been available have been unlimited in variation and scope.

The teaching of computer language to adults was the basis of televiced lessons afforded to the employees of the Fortran Company (Hartman and Behr, 1971). The mean of the pre-test percent scores averaged thirty-five, with a score of twenty-ifive being possible by chance alone. The mean of the post-test percent scores averaged eighty-nine. The Ford Notor Company fourd by using television in instructing acult indjiduais how to operate, maintain and repair gas turbine engincs, 90 percent of the trainees achieved 95 . percent of the objectives.

Results, such as those reported above, generally have not been readily accessible within the literature. The reporting of resulte appeared to be more general and less 


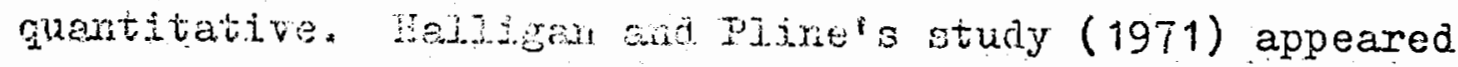
to typjify reanlts of now stodies:

The net result has been that one teacher, one. paraprofessionel, and ax instructional technology systern have provided 60 students the opportunity ror five hours ox learning unker professional supervision...

Extensive usage of tejevision as an fnstructional tool has been exemplitied in the literature. The following studies reflect the implications of research which has appeared in the literature with regard to the use of instructional television.

Effects Upon AduIts. Erophy (1971) has consolidated the findings of many studies into one report. The results of televised byping, as found at Mchigan State University, characterized all. the studies Brophy reported. Michigan State University's report stated:

Teachers can be relieved of much of the routine and monotonous duties of lesson planning if video tapes are used. Whey would be leit to explore new drills and problem-solving techniques and to correct student problems mich more quickly.

Gross (1972) studied the effectiveness of presenting the same material through two different media, i.e., television versus conrentioral classroon instruction. He found that there were ". . no significant differences between on-campus students and students taking the tejevised cuurses. . ." These results may or may not be quantitatively validated; the literature provided no substantiating data. 
In the stari of "rocontmen Goldfaden (1972) reported his findings by stiting : . Decalise the material is visual, they can undersignd and get the message." Again, quantitative data was not neported.

Effects Uoon (biliger. Bert (1972) and Barrera (1973) conducted stuaies involving school children. Belt's project involved teaching art via television, He implied positive findings concerning effectiveress, but his major contribution was that he found classroom attention to the program to be in the 95 through 98 percent range.

"Carrascojendas - KLRN's Bijongual Series" was the topic for Barrera's (1973) study. The televised series was used by 800 classrocms, teaching a total of 17,000 MexicanAmerican bilingual students. An evaluation of Barrera's results showed that". - chjlaren who viewed the programs improved in their knowledge of muticulture social environment, English langhage skills, physical environment, and cognitive development."

ihe studies with childrer and television appeared to be less represented in the literaturs. The Sesame Street evaluations (Bail and BoEatr, 1970), however, have provided an exception to this manner of reporting. Their study, concerning major findirgs with respect to television and children, provided an extensive emownt of quartitative data, i.e., measurable results. Their summarization in relation to Sesane Street and the resulting data was: 
(1) the more riewing the child did, the more he tended to Learn the projected concept; (2) those programs best learned by the chilaren were the programs which received the most amphesis and shinks in the area of television technology When being produced; and (3) formal supervision of leamers was not essential. Their second-year findings (Bogatz and Ball, 1971) supported above conclusions with an extensive amount of measurable data.

\section{Valiojation}

Fredrick Breintfeld (Weeliver, 1972) has found television not to be a popvlar teaching medium in the schools. He also stated that celevision has become an insignificant item in the school buaget mainly because it varies from long established curricula and administrative systems. "Solid attempts to use the medium effectively for instmational purposes are fev," he has stated.

Perhaps validation of learning results could be a means for television instruction to achieve its identity as part of the educational process. Validation, in this sense, denotes the ". . process in which the measure of success is the effectiveness with which a lesson accomplishes predetermined changes in student's behavior" (Maccullough, 1969).

There has been, to cate, a lack of validated data in the area of language concept learning in conjunction with video tape playback. There have been studies such as the 
Sesame Strest studies ware the "mesges" have been presented language concepts. Hitthe, ji eny data, however, has been reported on teaching Iangnage coroepts to a specific population using indivionaijzed oneepts. 
CHAPTER III

METHODS AND PROCEDURES

\section{Subjects}

The subjects for this study consisted of 151 students enrolled in six first grade classrooms in three schools within Fortland School District Number One, Portiand, oregon.

These first grade classes were composed of children with achievement levels and abilities which would likely be found in a "normal" classroon. The study included ail those children that a classroom teacher instructs within her selfconteined classroom.

The schools, A, B, and C, served student populations of slightly different socioeconomic levels. These levels had been determined by considering mean family income, percentage annual income under four thousand dollars, and percentage of childiren in welfare families. When considering these three paraneters as illustrated in Table I, it was determined that the oraer of socioeconomic level for the schools sampled was school A (lowest), school B (middle), . and schoo: C (highest of the three schools). 
TABLE I

INDIGATCRS OF SOCIOECONONIC LEVELS FOR PARIICIPAIING. SCHOOLS'S

\begin{tabular}{|c|c|c|c|}
\hline Socjosconomic Indicators & A & $\underset{B}{S c h o o l s}$ & C \\
\hline Mean Family Income & $\$ 8,275$ & $\$ 11,327$ & $\$ 11,375$ \\
\hline $\begin{array}{l}\text { Percent Annual Income Under } \\
\$ 4,000\end{array}$ & 18.7 & 6.3 & 8.7 \\
\hline $\begin{array}{l}\text { Percent of Children in } \\
\text { Welfare ramilies }\end{array}$ & 11.2 & 1.9 & 3.9 \\
\hline
\end{tabular}

\section{Examiner}

One speech pathology graduate student at the master's level constituted the examiner. The examiner administered a pre- ard post-language concept test.

\section{Instrumentation}

Proouction

The puppet shows were video taped using two Sarkes Tarzan one-inch Viajicon cameras. One camera was equipped with a five-tomo zoom lens, while the other camera was outfitted with rack-mounted lenses. This rack-mounted lens asseribly corsisted of four separate lenses: a $25 \mathrm{~mm}$, a 50 $\mathrm{mm}_{8}$ a $75 \mathrm{~mm}$, and a $135 \mathrm{~mm}$. A VSS-8A Sarkes Tarzan switcher was also used to facilitate smooth transitions between 
Mrera shots. Who viajo tape lised was half-inch Sony magnetio tope.

The atdio portion of the puppet shows were pre-recorded by thee individueis and the investigator. This was comrieted over a five hour period prior to the actual video taping. The audic was taped on a quarter-inch reel-to-ree? Robexts $770 x$ tape recorder lising Ampex 600 professional series audio tape.

The prodration personnel who video taped the puppet lessone consisted of two cameramen, one floor director, one engineer, arid ons person who acted as an overall director, switcher, and adio cortrolier. The investigator and one othes individual manipulated the puppets. The final product of the procuctiocs were six five-minute video taped puppet lessons. These lessons inrolved the two concepts of "dwelling" and "assistance."

\section{DIayback}

The presentation of the puppet lessons to the subjects was dore using a sony half-inch Tape Videocorder, model AY-3650. The AV-3650 was a portable EIAJ type-one, video tape recorder. The monitor used was a Sony CVM-192U, eighteen-inch, black and white portable monitor IV receiver. The AV-3650 and the monitor were mounted on a movable cart. Figure 1 illustrates the mounting arrangement for the recorder and monjtor. 


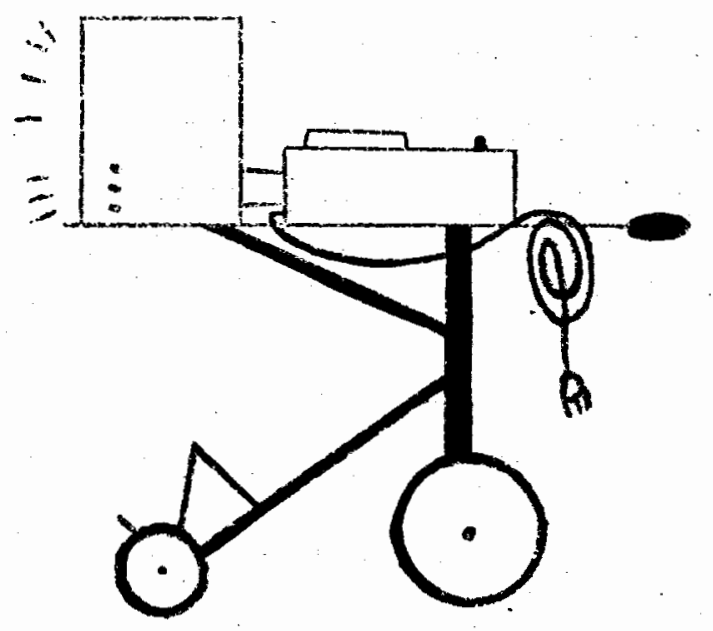

Figure 1. AV-3650 Sony video tape reconder with Sony CWN-192U Fionitior mounted on porsaule viewing cart.

The video taped lessons were shown in the classrooms with the sibjects seated at their desis. For every presentation of the video tapes, the monitor was not placed away from the window. All lights in the room were turned off except those at the opposite end of the room from where the monitor was located. These precautions were taken to eliminate possible monitor or window glare.

\section{Procedures}

The participating classroom teachers received instructions from the investigator not to discuss the concepts with the subjects until after post-testing was completed. The teachers agreed to this request. This was done in an attempt to eliminate extraneous variables which might in- 
fluence the study's results.

The investigetor expleinsa nis initial presence in the classroom by talling the subjects:

I am going to ask woi to do some things with this booklet [nre-test]. When we hare tinished making $\mathrm{X}^{\prime} \mathrm{s}$ on the pictures I vill collegt hex from you. In about a week I will be back to see you with a surprise [video tapea nuppet lessons].

Three concepts wich vere found by Dunn (1959) to be above fourth grade level were purposely chosen to result in a low pre-test score, The booklet pre-test, therefore, consisted of three picture plates ("dwelling" "assistance," and "edifice") fror the Peabody Pjcture Vocabuiary Test, Form B (Dunn, 1959). The prentest was administered to the subjects as a group, each receitring a separate test booklet. The results of this concept test provided baseline data as to which concepts were not known. From the uninown concepts, two concepts, "dwelling" and "assistance," were chosen which the majority of the children within the classrooms did not possess.

Randomly the two concepts were divided equally among the six classrooms, i.e., three classrooms were assigned the concept of "dwelling" and the remaining three classrooms were assigned the other concept of "assistance." The third concept "edifice," was eliminoted from the study due to a high success rate on the pre-test for that concept. It was the investigator's belief that the high success rate was due to the fact that the picture corresponding to the word "edi- 
ficel was aifferent pou the atcmate choices, i.e., the "edifice" picture vas a complete bulajing; whereas, the other three choices consisted of froctions of architectural structures.

The concepts seleoted by the above procedure were presented to the subjechis by neans of vides tape playback. The video taped lessons were recorded prios to being presented in the olassmom. Bach presentation consisted of three separate, but releted, video taped programs based on a single concept (see Appendix $A$ and $B$ ). The three programs were presented to each classroom on three successive days, i.e., each concept was presented in a three-part Jesson, one part per day for three deys. Each iesson employed a puppet show using puppets from the peabody Langrage Kit (Junn and Smith, 1966) and homerade puppets borrowed from Dr. Robert W. Vogelsang, Chairman, Department of Speech Communication, Portland State University.

A post-test, following three days of language intervention, was administered after a one day period of non-intervention. The post-iest consisted of: the original three plates, "dwelling," "assistance," "edifice," and four additional plates. The four additional plates illustrated the specific concept presented to each classroom. Hence, two individual post-test booklets were constructed. The posttest was a paper and pencil test as was the pre-test. It was admintstered to each classroom as a group by the examiner. 


\section{Data Mrajyess}

The results of the pre-test were scored as eitiner right or wrong for each plate tested. Criterion for considering a concept as being laarned was at least four of

- five correct responses on the post-test of five plates containing items for the concept taught. Results were reported in percentages.

Absences were not taken into account when ankilyzing the data. Since the lessons were presented to groups of subjects and not individuals, absenteeisms were not considered significant for this study. The data was not significantly affected due to this procedure except in the computation of the concept "assistance" for the female population. 
CHAPTER IV

\section{RESUITS AND DISCUSSION}

\section{Results}

\section{Overall Findings}

The post-test reslilts for woth concepts "dwelling" and "assistance" indicated 94.46 percent of the subjects responded accurately for at least four of the ifve piates. This compared to 19.33 pexcent responding accurately to the pre-test. Hence, there was a 75.13 percent increase in accurate response to the concepts from pre-test to post-m test (see Figure 2).

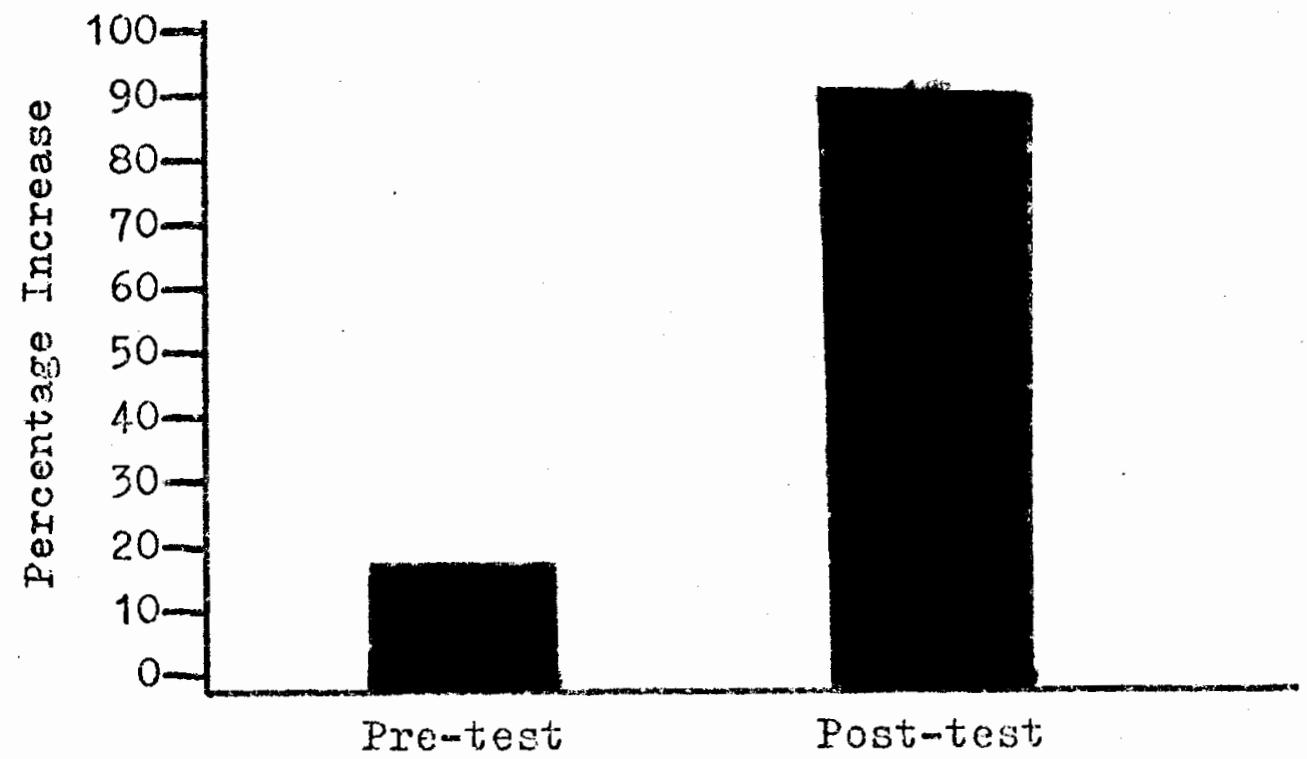

Figure 2. Overall increase in correct response to the concepts based upon pre-test and post-test scores. 


\section{Dwelling}

The post-test findings for the concept "dwolling" indicated 98.59 percent of the subjects present responded accurately for at least four of the five plates as compared to 1.31 percent responding accurately to the pre-test. There was, therefore, a 97.28 percent increase in the number of students responding correctly to the concept after the video taped presentations. Table II elso illustrates results for the individual schools.

TARLE II

SUCCESS RAPIO FOR ALI SCHOOLS FROM FRE-

TEST TO POSA-TEST FOR THE CCHCEFT

"DWELILLAG" ( $\mathrm{i}=71)$

\begin{tabular}{|c|c|c|c|c|c|c|}
\hline \multirow[t]{2}{*}{ Schools } & \multicolumn{2}{|c|}{$\begin{array}{l}\text { No of Subjects } \\
\text { Responding Corm } \\
\text { rectly }\end{array}$} & \multicolumn{2}{|c|}{$\begin{array}{l}\text { No. of Subjects } \\
\text { Responding In- } \\
\text { correctly }\end{array}$} & \multicolumn{2}{|c|}{$\begin{array}{l}\text { Success Ratio For } \\
\text { Presented Concept }\end{array}$} \\
\hline & $\begin{array}{l}\text { Pre- } \\
\text { test }\end{array}$ & $\begin{array}{l}\text { Post- } \\
\text { test }\end{array}$ & $\begin{array}{l}\text { Pre- } \\
\text { test }\end{array}$ & $\begin{array}{l}\text { Post- } \\
\text { test }\end{array}$ & $\begin{array}{l}\text { Pre- } \\
\text { test }\end{array}$ & $\begin{array}{l}\text { post- } \\
\text { test }\end{array}$ \\
\hline$A$ & 0 & 20 & 21 & 0 & $0 \%$ & $100 \%$ \\
\hline$B$ & 0 & 21 & 23 & $i$ & $0 \%$ & $95.45 \%$ \\
\hline c & 1 & 29 & 27 & 0 & $3.93 \%$ & $100 \%$ \\
\hline$A, B, C$ & 1 & 70 & 71 & 1 & $1.31 \%$ & $98.59 \%$ \\
\hline
\end{tabular}

\section{Assistance}

For the concept of "assistance," post-test scores indicated 90.43 percent of the subjects present responded 
wecurately for at least four of the five plates, 5.48 perm cent responded accurately on three of the five plates, and 1.37 percent responded appropriately on two of the five plates. There was, therefore, a 53.04 percent increase in the number of subjects responding correctly to the concept after the video tape presentation. Table III further illustrates these findings.

TABLE III

SUCCESS RATIO FOR ALI SCHOOLS FROM PRETEST TO POST - TEST FOR THE CONCPPT

"ASSISTANCE" ( $N=73)$

\begin{tabular}{|c|c|c|c|c|c|c|}
\hline \multirow[t]{2}{*}{ Schools } & \multicolumn{2}{|c|}{$\begin{array}{l}\text { Ho. of Subjects } \\
\text { Responaing Cor- } \\
\text { rectly }\end{array}$} & \multicolumn{2}{|c|}{$\begin{array}{l}\text { No. of Subjects } \\
\text { Respondine In- } \\
\text { correctiy }\end{array}$} & \multicolumn{2}{|c|}{$\begin{array}{l}\text { Success Ratio For } \\
\text { Presented Concept }\end{array}$} \\
\hline & $\begin{array}{l}\text { Pre- } \\
\text { test }\end{array}$ & $\begin{array}{l}\text { Post- } \\
\text { test }\end{array}$ & $\begin{array}{l}\text { Pre- } \\
\text { test }\end{array}$ & $\begin{array}{l}\text { Fost- } \\
\text { test }\end{array}$ & $\begin{array}{l}\text { Pre- } \\
\text { test }\end{array}$ & $\begin{array}{l}\text { Post- } \\
\text { test }\end{array}$ \\
\hline A & 4 & 18 & 18 & 2 & $18.18 \%$ & $90.00 \%$ \\
\hline$B$ & 17 & 23 & 10 & 2 & $62.96 \%$ & $92.00 \%$ \\
\hline $\mathrm{C}$ & 9 & 25 & 20 & 3 & $31.03 \%$ & $89.29 \%$ \\
\hline$A, B, C$ & 30 & 63 & 48 & 7 & $34.06 \%$ & $90.43 \%$ \\
\hline
\end{tabular}

Concept Not Presented

In each classroom knowledge of both concepts ("dwelling" and "assistance") was tested prior to and following the video taped presentation. Of the subjects who viewed the tapes on "dwelling" only 8.93 percent more, responded 
correctly to the plate testing the conoept of "assistaxcen (see Figure 3).

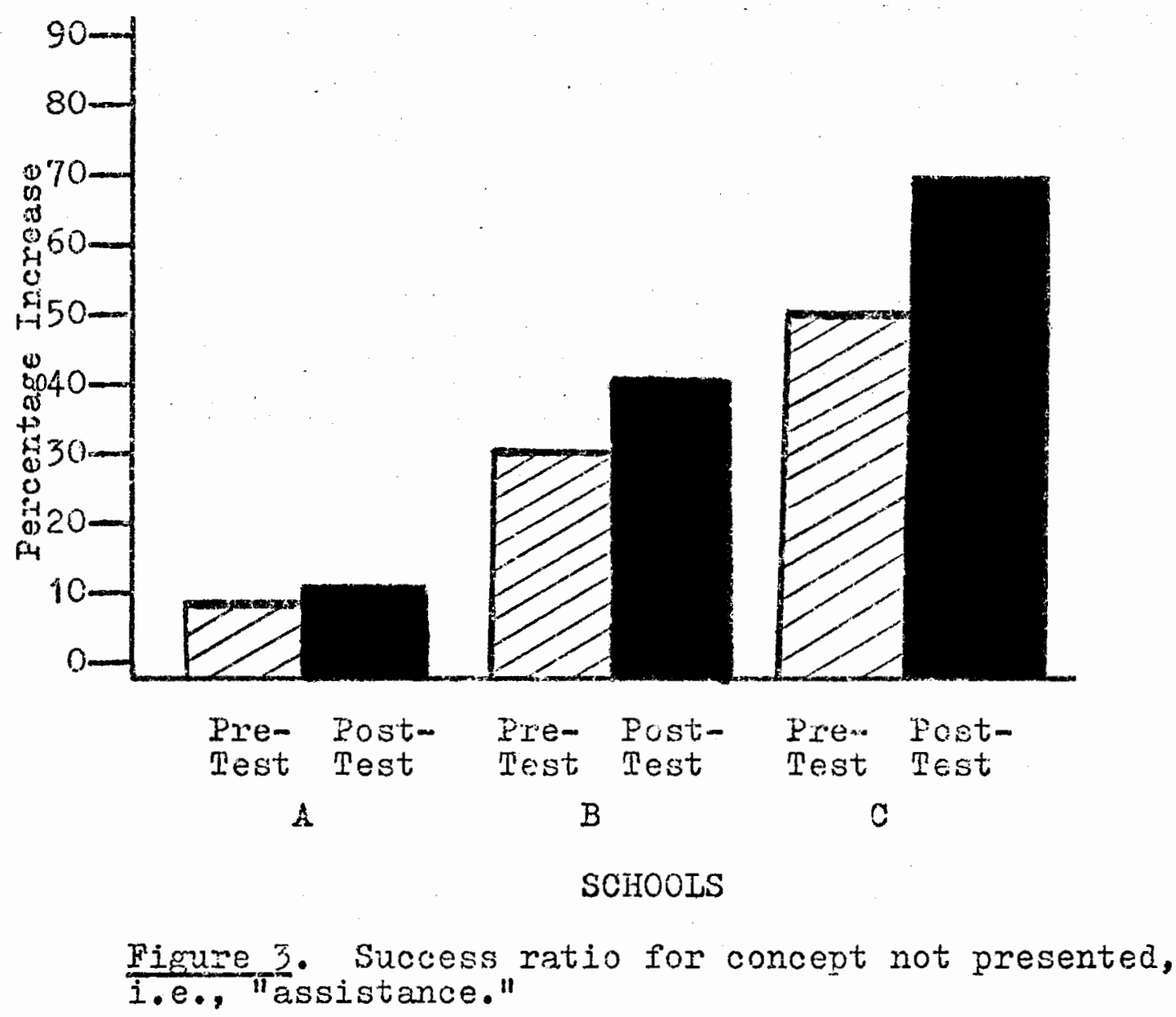

Similarly, of the subjects who viewed the presentations on "assistance," only 1.98 percent more responded correctly to the plate testing the concept of "dwelling." For both concepts not presented, there was an overall increase of 5.46 percent of the subjects who demonstrated "knowledge" of the corcept (see Figure 4 ).

\section{Ratios According to Sexes}

Male. Phe post-test results for both concepts, 


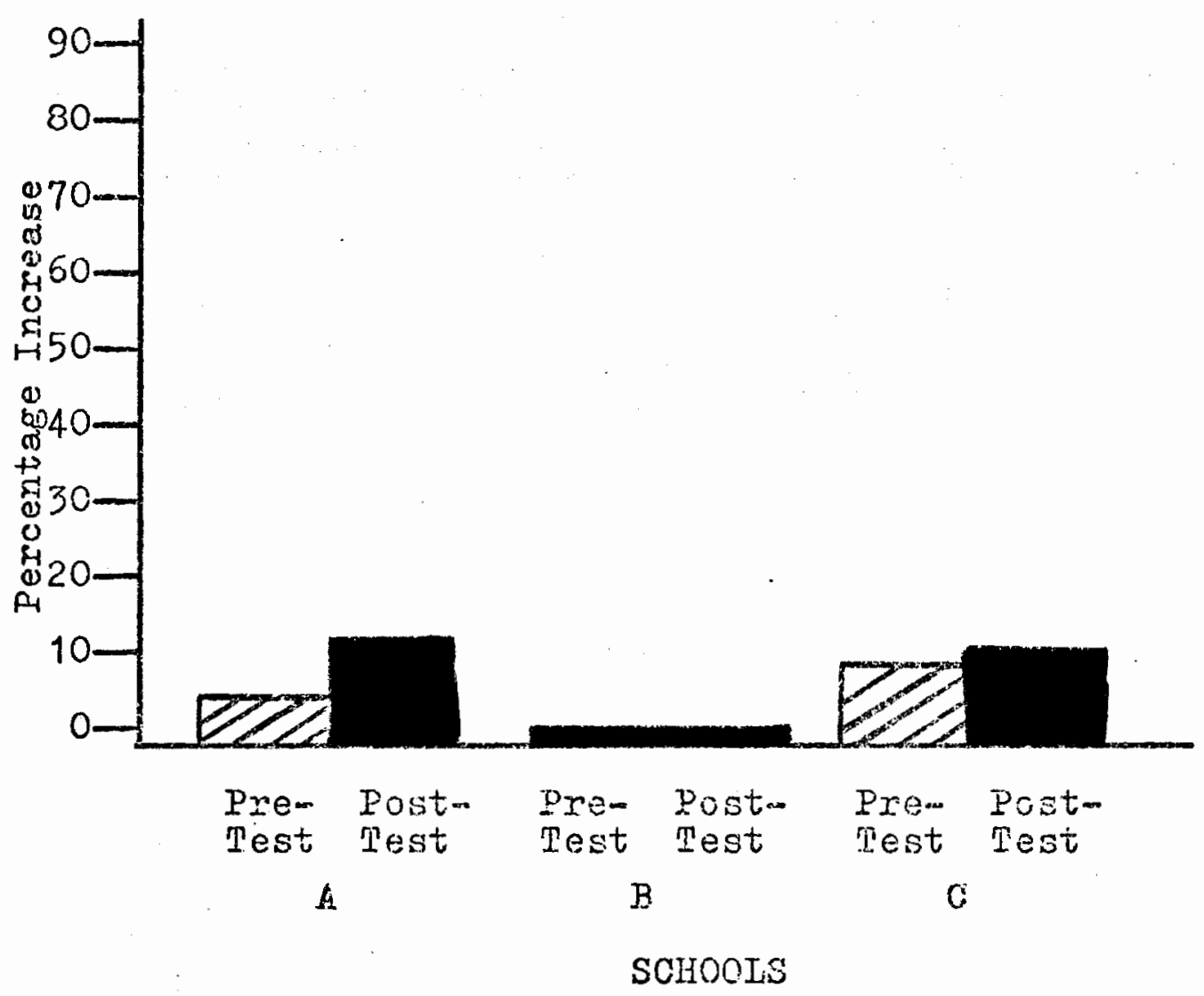
$\frac{\text { Figure 4. Success ratic for conopt not presented, }}{\text { i.e., "dwelling." }}$

"dwelling" and "assistance," indicated 96.67 percent of the subjects responded correctly for at least four of the five plates. In comparizon, the pre-test scores indicated only 15.84 percent responded correctly. An 80.83 percent increase from pre-test to post-test, therefore, was achieved (see Figure 5).

Pre-test scores for the concept "dwelling" indicated zero percent of the nale subjects responded correctly (Table IV). Upon post-test, 100 percent of the subjects present dsmonstrated correct responses for at least four 
the fire plates. This was a 100 pexcent increase of correct reponse over pre-test scores.

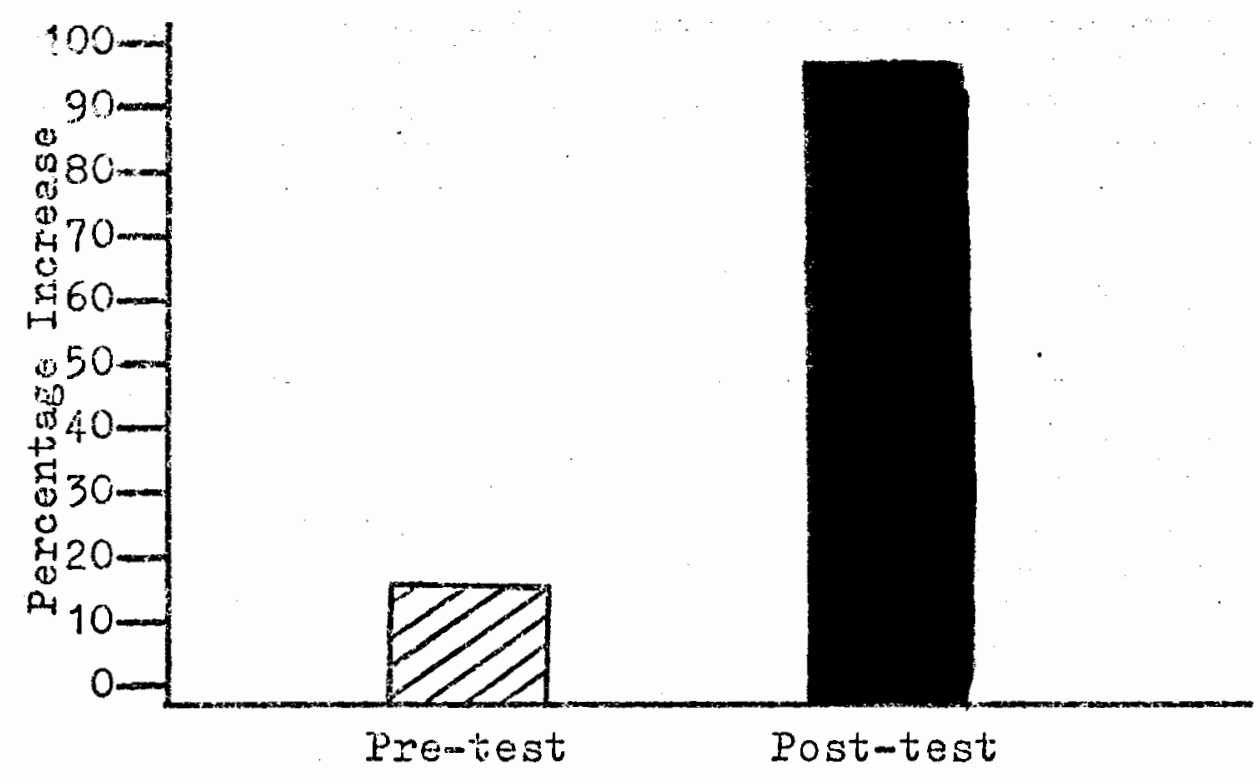

Figure 5. Overall correct responses indicated by male subjects for both concepts.

\section{TABLE IV}

MATE SUCCESS PATIO FOR ALI SCHOOIS FROM

PRE-TEST TO POST-TEST FOR TEE CON-

CEPT "DWELIING" ( $N=42)$

\begin{tabular}{|c|c|c|c|c|c|c|}
\hline \multirow[t]{2}{*}{ Schools } & \multicolumn{2}{|c|}{$\begin{array}{l}\text { Correct } \\
\text { Responses }\end{array}$} & \multicolumn{2}{|c|}{$\begin{array}{l}\text { Incorrect } \\
\text { Responses }\end{array}$} & \multicolumn{2}{|c|}{$\begin{array}{l}\text { Success Ratio For } \\
\text { Presented Concept }\end{array}$} \\
\hline & $\begin{array}{l}\text { Pre- } \\
\text { test }\end{array}$ & $\begin{array}{l}\text { Post- } \\
\text { test }\end{array}$ & $\begin{array}{l}\text { Pre- } \\
\text { test }\end{array}$ & $\begin{array}{l}\text { Post- } \\
\text { test }\end{array}$ & $\begin{array}{l}\text { Pre- } \\
\text { test }\end{array}$ & $\begin{array}{l}\text { Post- } \\
\text { test }\end{array}$ \\
\hline A & 0 & 15 & 16 & 0 & $0 \%$ & $100 \%$ \\
\hline$B$ & 0 & 13 & 13 & 0 & $0 \%$ & $100 \%$ \\
\hline 0 & 0 & 14 & 14 & 0 & $0 \%$ & $100 \%$ \\
\hline$A, B, C$ & 0 & 42 & 43 & 0 & $0 \%$ & $100 \%$ \\
\hline
\end{tabular}


The pre.test score for the concept "assistance" indium catid 50.02 percont of the male subjects responded correctily (wable V). Vnon post-testing, 93.33 percent of the slibjects present demonstrated correct responses for at least four of the five plates. This was a 63.28 percent increase of correct response over pre-test scores.

\section{TABLE V}

MATE SUCOESS RATIO FOR AII; SCHOOIS FROM

PRE-TEST TO FOST-TES $T_{1}$ FOR THE CON-

CEPT "LSSISTANCE" ( $N=42)$

\begin{tabular}{|c|c|c|c|c|c|c|}
\hline \multirow[t]{2}{*}{ Schools } & \multicolumn{2}{|c|}{$\begin{array}{c}\text { Correct } \\
\text { Responses }\end{array}$} & \multicolumn{2}{|c|}{$\begin{array}{l}\text { Incorrect } \\
\text { Responses }\end{array}$} & \multicolumn{2}{|c|}{$\begin{array}{l}\text { Success Ratio For } \\
\text { Presented Concept }\end{array}$} \\
\hline & $\begin{array}{l}\text { Pre- } \\
\text { test }\end{array}$ & $\begin{array}{l}\text { Post } \\
\text { test }\end{array}$ & $\begin{array}{l}\text { Pre- } \\
\text { test }\end{array}$ & $\begin{array}{l}\text { Post- } \\
\text { test }\end{array}$ & $\begin{array}{l}\text { Pre- } \\
\text { test }\end{array}$ & $\begin{array}{l}\text { Post } \\
\text { test }\end{array}$ \\
\hline \& & 1 & 12 & 12 & 0 & $7.69 \%$ & $100 \%$ \\
\hline$B$ & 7 & 15 & 8 & 0 & $46.67 \%$ & $100 \%$ \\
\hline $\mathrm{C}$ & 5 & 12 & 9 & 3 & $35.71 \%$ & $80 \%$ \\
\hline$A, B, C$ & 13 & 39 & 29 & 3 & $30.02 \%$ & $99.33 \%$ \\
\hline
\end{tabular}

Fernale. The post-test results for both concepts "dwelling" and "assistance" indicated 90.65 percent of the female subjects responded correctly to the concepts for at least foux of the five plates (see Figure 6). The pre-test scores, in contrast, indicated only 25.16 percent of the subjects responded correctly. From pre-test to posttest, a 65.49 percent increase, therefore, was noted. 


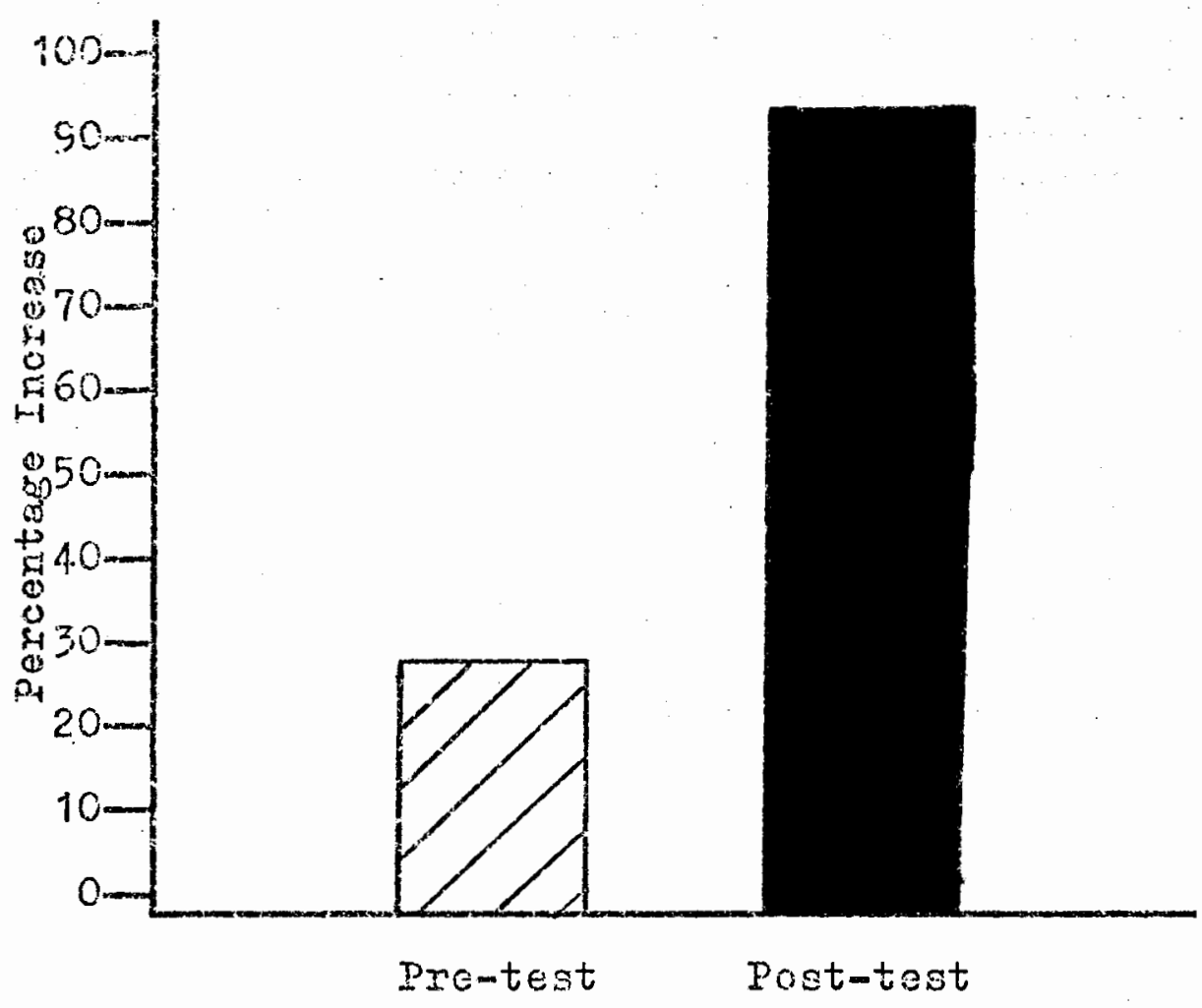

Ficure 6. Overal] correct responses indicated by female subjects for both concepts.

A premtest score of 2.38 was achieved by the female subjects for the concept "dwelling." Post-test scores for the same concept indicated 96.30 percent of the female subjects present demonstrated correct responses on at least four of the five plates, resulting in an increase of 93.92 percent (see Table VI).

The pre-test score for the concept "assistance" indicated 47.78 percent of the female subjects responded correctly (see Table VII). Upon post-testing, 85 percent of the subjects present demonstrated correct responses for at least four of the rive plates. This was a 37.22 percent increase of correct responses over pre-test scores. 
TABLE VI

TEMLIJE SUCCESS RATIO FOR ALI SCHOOLS FROM PRE-TESI TO FOST-TEST FOR THE CONCEPT

"DWEILING" ( $N=29)$

\begin{tabular}{l|cc|cc|cc}
\hline Scrools & $\begin{array}{c}\text { Correct } \\
\text { Responses }\end{array}$ & $\begin{array}{c}\text { Incorrect } \\
\text { Responses }\end{array}$ & \multicolumn{2}{|c|}{$\begin{array}{c}\text { Success Ratio For } \\
\text { Presented Concept }\end{array}$} \\
\hline A & $\begin{array}{c}\text { Pre- Post- } \\
\text { test }\end{array}$ & $\begin{array}{c}\text { Prest } \\
\text { test }\end{array}$ & $\begin{array}{c}\text { Post- } \\
\text { test }\end{array}$ & $\begin{array}{l}\text { Pre- } \\
\text { test }\end{array}$ & $\begin{array}{c}\text { Post- } \\
\text { test }\end{array}$ \\
0 & 5 & 5 & 0 & $0 \%$ & $100 \%$ \\
B & 0 & 8 & 10 & 1 & $0 \%$ & $88.89 \%$ \\
1 & 15 & 13 & 0 & $7.14 \%$ & $100 \%$ \\
A, B, C & 1 & 28 & 28 & 1 & $2.38 \%$ & $96.30 \%$ \\
\hline
\end{tabular}

TABLE VII

FHMALE SUCCESS RATIO FOR ALI SCHOOIS FROM

PRE-TEST TO POST-TEST FOR THE CONGEPT

"ASSISTANCE" ( $N=30)$

\begin{tabular}{|c|c|c|c|c|c|c|}
\hline \multirow[t]{2}{*}{ Schools } & \multicolumn{2}{|c|}{$\begin{array}{l}\text { Correct } \\
\text { Responses }\end{array}$} & \multicolumn{2}{|c|}{$\begin{array}{l}\text { Incorrect } \\
\text { Responses }\end{array}$} & \multicolumn{2}{|c|}{$\begin{array}{l}\text { Success Ratio For } \\
\text { Presented Concept }\end{array}$} \\
\hline & $\begin{array}{l}\text { Pre- } \\
\text { test }\end{array}$ & $\begin{array}{l}\text { Post- } \\
\text { test }\end{array}$ & $\begin{array}{l}\text { Pre- } \\
\text { test }\end{array}$ & $\begin{array}{l}\text { Post- } \\
\text { test }\end{array}$ & $\begin{array}{l}\text { Pre- } \\
\text { test }\end{array}$ & $\begin{array}{l}\text { Post- } \\
\text { test }\end{array}$ \\
\hline$A$ & 3 & 6 & 6 & 2 & $33.34 \%$ & $75 \%$ \\
\hline$B$ & 10 & 8 & 2 & 2 & $83.34 \%$ & $80 \%$ \\
\hline C & 4 & 13 & $i 1$ & 0 & $26.67 \%$ & $100 \%$ \\
\hline$A, B, C$ & 17 & 27 & 19 & 4 & $47.78 \%$ & $85 \%$ \\
\hline
\end{tabular}


Ratio Accordins to socioecononic Jevels

School A. Iosturest scrres indicated that 95 percent of the subjects in school a, the lowest sociceconomic level represented, responded correctly to the coricept they had been presented via viden tape piayback, this was an 85.91 percent increase in correot responies over pre-test score (Figure 7).

School B. Jpon post-testing school $B$, which was the middle socioeconomic level represented, 94.64 percent of the subjects responder correotiy to the concept they had monitored for the three days. This was a 77.16 percent increase in correct responses over the premest score (Figure 7).

Schoold. Fesults from postatesting indicated 93.72 percent of the subjects in schocl $C$, the highest socioeconomic level represented, responded correctly to the concept presented to them. This was a 62.28 percent increase over the pre-test score (Figure 7).

\section{Discussion}

The resuits of this study have indicated the resulting data to be quantifiable and significant. The overall post-test scores revealed that more than 90 percent of the subjects responded accurately to the test items for both concepts. As a comparison to the noted subsiantial increase between pre-iest; and post-test, an increase for those concepts presented of 75.13 percent was obtained; whereas a 


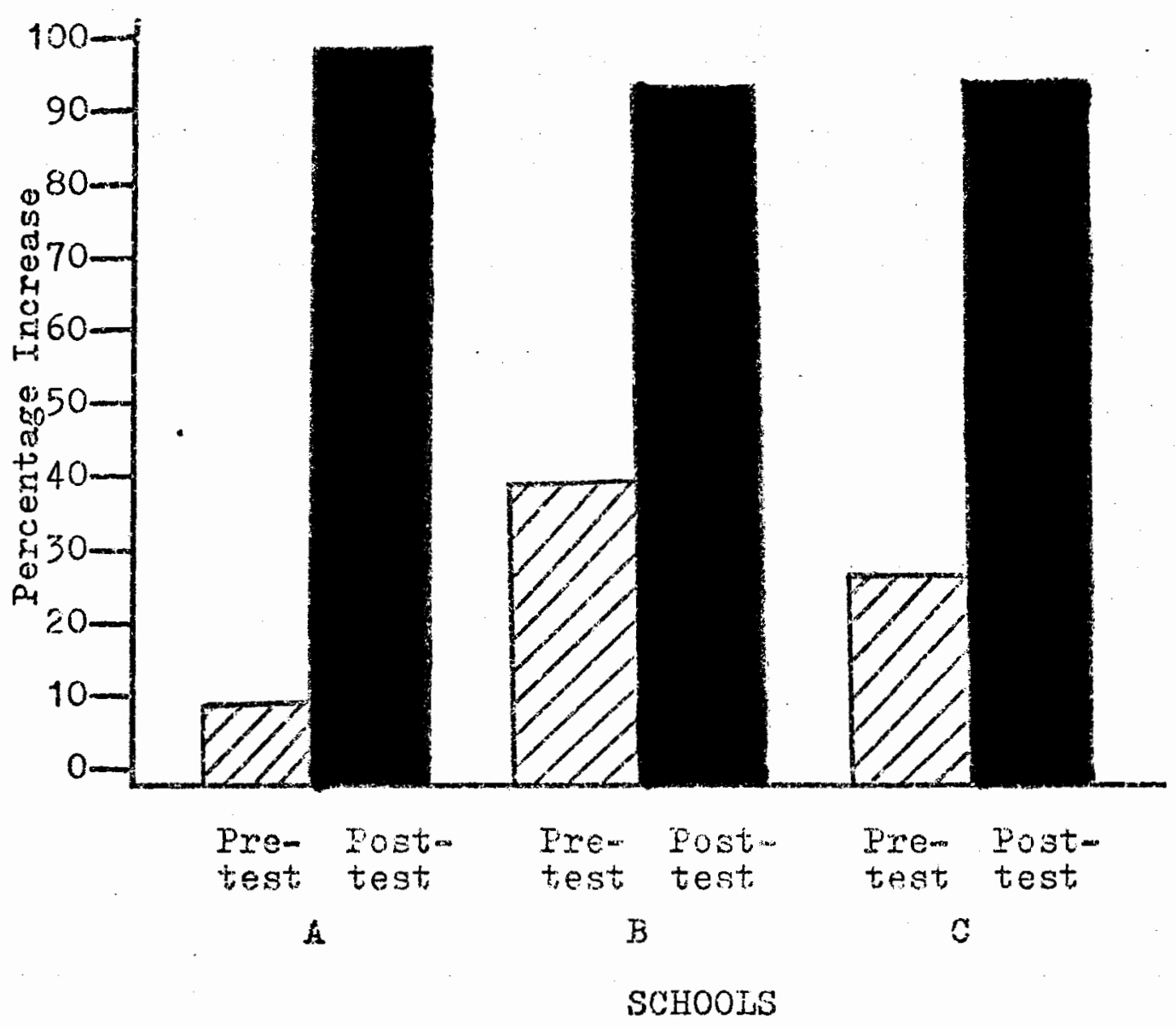

Figure 7. Percentage of stiderts within a given school indicating "knowledge" of the concept presented to them via video tape playback.

vexy minimal increase, $5,4.6$ percent, occurred for the concept of "edifice" which was not presented.

Individually, the number of students correctly

responding to the concepts "dwelling" and "assistance" increased 97.17 percent and 53.04 percent respectively over the pre-test scores. An explanation ror this large discrepancy lies in the fact that a larger percentage of the subjects identified "assistance" than "dwelling" on the pre-test. Even though the percentages of increase differ 
by 44.13 percent, the percent of pubjects responding correctly to the concept as indicated by post-test scores, was similar; 98.59 percent eno 90.41 percent respectively. The grammatical aifference noted between the two words, "dwelling" being a rown and "assistance" being a noun derived from a verb, may or mey not have affected pretest scces and consequently incluenced overnil increases in correct response for individuaj conoepts. Jpon pretesting, the concept of "assistance"l was correctly identified by 37.39 percent of the sujjects while the concept "dwelling" was correctly identilied by only 3.93 percent of the subjects. The increase in percentage of subjects correctly idertifying "assistance" ( 53.04 percent) was less than the percertage of the subjects correctly identifying the concept "dwelling" (97.17 percent). Final percentage responding correctly to the concept, however, was similar (Figure 8).

For the concepts not presented, but tested for preand post-test results, only 8.93 percent increase, in comparison to the 75.13 percent increase for the concepts presented, was not considered a significant increase by the investigator and was probably due to "chance" factors.

There appeared to be no significant difference between the percentage of male and femaie correct responses for either concept. For both concepts "dwelling" and "assistance" the percent of males and females correctly respond- 


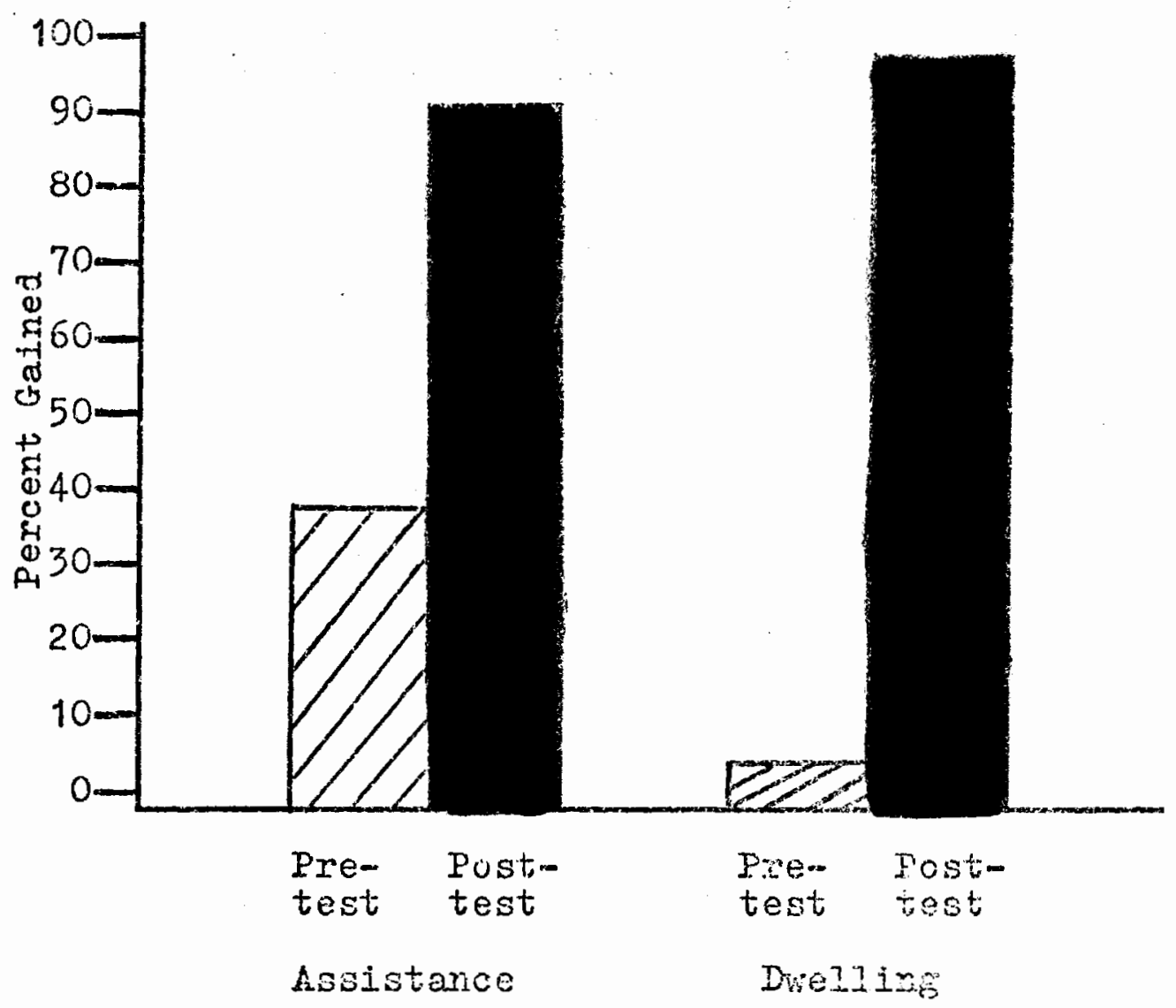

Figure 8. Percentage of subjects cemonstrating "inowledge" of concept on prew and post-iest.

ing, for at least four of the five plates, was 96.67 percent and 90.65 percent respectively.

The overall percentage of suijects, who denonstrated correct response to the soncepts upon post-testing, varied within 1.28 percent for ali schools which were of three different socioeconomic levels. The investigator did not consider this to be a large enough variance to be classified as significant, especially since 93.72 percent or more of the subjects in all schools responded correctiy to the concept upon postutesting. The small variance among socioecononic levels may have existed because this study may not 
in fact have diferembth "xean" socioeconomic levels.

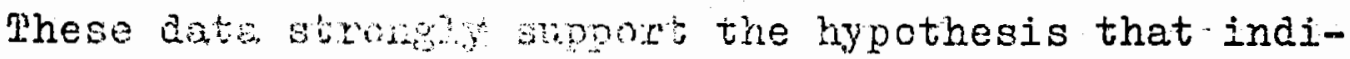
vidualized language conests car be taught through video tape playback using the rethoda and procedures previously described. It was feld by the invostigator that the results obtained were a direct result of the suijects prior television watching lelaviors, the "fantesy" of puppets, and the standardization of presentation enployed by the investigator. This study did not compare these methods and procedures to those of human instrnictors or any other mechanical audio-visual aide. Had this been the format for the study, comparable results may or may not have occurred.

In, however, professionel promecordea video tapes had been used one might have axpected to cbtain even higher and more significant results. As previously stated, Ball and Bogatz (1970) found that those programs best learned by the children were the programs which received the most emphasis and skills in the area of television technology when being produced. It is the opinion of the investigator that speech clinicians preparing video tapes for their clients would probably not have the facilities, skill, or time to produce an elaborate video tape playback. It has been postulated by the investigator that a simple three- to five-minute preseritation produced by one or two persons mignt yield results nearly as high as professionaliy produced prerecorded tapes. The "locally produced" non-professional 
tepe might also have the acect sarntage of being more readily acceptea by he "lcoal" smool.

This "Iocal" aosoptano way heve been one of the reasons for the initial Eceptance of the study by the participating teachers. The acceptrace was so favorable that the news of the study traveled quickly among classrooms, so rapidiy that a mumer of non-participating teachers wanted to know if their classroom coula be involved in the study. The school speech clinician at school B viewed the final presentation with the subjects and later reflected that the possibilities were great as to the pany uses the video tape presentations could provide for her treatment sessions.

It was the investigator's opinion, based upon teacher's comments and questions, that the teachers were sincerely interested in the theory and methodology of presenting a lesson via viàeo tape to their classroom. 
JEAPTER $\mathrm{V}$

SUNWARY AND TMPIICATIONS

\section{Summary}

Educational television began in 1932 at the State University of Iowa. Intil 1952, the potential of its contributions to education were not fully recognized. In 1952, however, the Federal Commication Commission created nonconmercial television stations. From that point in time, educational television has mushroomed.

Ever though much has been done in the field of educational television, reported studies with validated results were found to be few. The sesame Street evaluations appeared to be an exception. A large amount of literature describing the results of presenting a skill to the general population was found. Nothing, however, was found relating to the teaching of a speoific language concept to a designated specific group other than those studies presented to the "masses."

Phis study tested the hypothesis: At least 80 percent of a given first grade population will respond accurately to the post-testing of a language concept, after the concept has been presented to them via a video tape playback using puppetry as the teaching nethod. In essence, 
the study wes desibned to letemine wether or not an inaividualized concept conle be presented to a specific population using the evove nethocs and procedures. The study was also designed to deterutio wheiher a nale-female difference existed in learming languege concopts and whether or not there existed differences among scojoeconomic levels. The subjects for this study consisted of a sample of students from six first grade classes within Fortland School District Number one, Portlend, Oregon. The examiner consisted of one specch pathology graduate student at the master's level. The investigatox administered a language concept test for determining pre- and post- results.

From the langlage concepts pre-test, two concepts, "dwelling" and "assistance" (both from the Peabody Picture Vocabulary Test, Form B), were chosen to be the presented concepts. Each of three different five-minute video tape playback presentations were then shown to the subjects on three consecutive days. A post-test, following the three days of language intervention, was auministered after a one day period of non-intervertion.

The results indicated a very high success rate for learning the language concepts, i.e., 53.04 percent increase for "assistance" and 97.17 percent increase for "dwelling." It was also found that no great vaxiations existed in increase of correct responses for males and females. Socioecoromic differences were not found to be significant 
Which may have been due to investigetor exror wh thoging the school to represent each scioeconomic level. Tt this concluded that a specifjc language concept can be banght to a predetermined first grade population via video tape playback using puppetry as the teaching method.

The highly significant results may not have oceurred if the study had used different methods and procecures while employing a video tape playback syster. The results which were obtained in this study, indicated that by using the prescribed methods of puppetry, the concepts vere learned in a short period of tine with resuits wihich were quantifiable and valid.

\section{Implications}

Q]inical

The findings of this study may provide the speech clinician with an efficient, effective, and time-saving method for teaching basic concepts to first grade students. It would not be unrealistic to imagine a viewing room within the school so that all the children who had been identified as lacking a specific concept could view the monitor at a specified time for that specific concept, thus allowing personalized learning for those who had a language concept deficit. The video tape of a specifjc concept could be shown several times; herice, the students who just moved into the school and the students who did not grasp the 
concept, could be re-programed taxough the lesoons.

Due to the simplicity of showing a video tape, an older student or teacher's aide could manage the playback sessiors, thereby releasing valuable treatment time for the speech clinician. This redistributed treatment time, which would have been spent teaching basic concepts, could possibly be spent with students who had a lrore severe speech and/or language impairment.

\section{Resegr:ch}

It is suggested trat further research be done using teaching methods other then puppets. While using different methods, i.e., live presentations video taped, professionaliy produced viceo tapes, or purchased "canned" tapes, a wider range of concepts should be employed.

To determine if the present results were representative of first grade classes in general, a larger population sample needs to be considered. Valuable information pertaining to this study may also be obtained by sampling other gracie levels.

In a future study, it is also recommended that a discussion time be included immediately following the playback presentation. This study was not designed for such a procedure. Such discussions, however, may significantly alter the time needed to teach a coricept.

The iypothesis of this study was based upon the premise that a given population could learn a specific 
Iangange concept presented via video tape playback usine pupvets as the teaching method. The results substantiated the hypothesis; subjects can learn a language concept when presented to tiien using the above methods and procedures in a relatively short period of time. Future research is needed to explore and expand the results and implications this study has provided. 


\section{REFERENCES CITED}

Ba]. . 5. and Bogatz, G., The first year of sesame street: an evaluation. Educational Testing Service, Princeton, New Jersey (1970).

Barrera, A. Cerrascolendas - KIfur's bilingual series. Eduoational and Industrial Ielevision, 5 (1), 23$25(1973)$.

Beit, F., Inages and things: excitement in classrocr art. Educationel and Industrial Television, 4 (4), 15-18 (1972).

Bogatz, G. and Ball, S., The second year of sesame street: a continuing evaluation. Educational Testing Service, Princeton, New Jersey (1971).

Brophy, J., VTR integral to classroom instruction. Audiovisual Instruction, $16(4), 35-38(1971)$.

Dunn, I., Peabody Picture Vocabulary Test. Anerican Guidance Service, Inc., Circle Pines, Minnesota (1959).

Dhinn, I, and Smith, J., Peabody Iançuage Development Kits. American Guidance Service, Inc., Circle Pines, Minnesota (1966).

Goldfaden, B., Videolingua. Educational and Industrial Television, 4(8), 22-34(1972).

Gross, I. S., A study of two college credit courses offered over television by the southem California consortium for community college television. A paper presented to the California Association for Educational Media and Technology. United States Department of Health, Education and Welfare, 1-29 (1972).

Gross, I., The "real" world of telavision. The Journal of the National Education AEsociation, 63 (1), 86$92(1974)$.

Halligan, W. and Pline, N., Band-aids ox surgery. Audiovisual Instruction, $15(9), 40-42$ (1971). 
Hartnar, I. and bne, a a videctaped course designed to

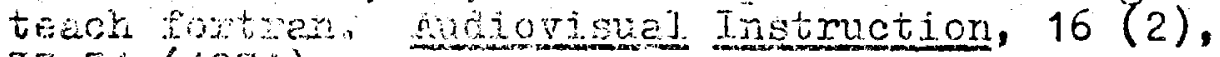
$33-34(1971)$.

Full, $R_{n}$, me developrent of education television in the United States. Northwest enfierence on pelevision

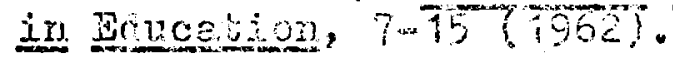

Maccullough, $D_{c}$, Is vajlation what ITV really needs? Edicationa? Instructional Broadcasting, 30-34 (1969).

Mayer, T., Children's pepeoptions of favorite television onaracters as bonavioral models. Educaticnal Broadcasting Review, ? (1), 25-33 (1973).

Palmer, L., Formative raseaich in the production of $t . v$. for childzen. A paper presented to the Chilaren's Television Worksnop, Hew York, N.Y., 1-31 (1973).

Selden, S., Some cultural limitations to visual aids. Audiovisual Instruction, 16 (1), 15-16 (1971).

Weeliver, P., IrV and educational change: area for reEearch. Educational ario Industrial Television, 4 (3), $10(3972)$. 
SPPETISI A

VIDEO IAPED LESODN PRESEATING THE CONCEPT

ON "DWELING"

Dirst yay' Presertation

Mr. Book Worm: Mi boys and girls, my nane is Mr. Book Worm. I'm called Mr. Book Worm because I like to read. I read everything. Foday I'm going to rea you a story. (LOOKS AROUND FOR BOOK) On my, where i.s my book? I just had it right here. (JOOKS AROUND - SPORS IT BACK SPAGI) There it is!! It must heve fallen dorm there when I wasn't looking. I'II need some help to get the book. Who can I get to help me? (LOOKS AROUND) Is there no one here to help? (LOOKS AROUID AGAIN; BEGINS TO CRY) I wanted so very much to read Jou a story today, but I can't pick arything up as big as a book, for I have no hands. (CRIES AGAIN)

Miss Elephant: (INTERS) Hi Mr. Book Worm!

Mr. Book Worm: Oh gee Miss Elephant, would you give me some help in getting ry book?

Miss Plephant: (IOOKS OVER EDGE TO WHER THE BOOK IS LYING) I would help a friend anyday - and you are surely a good friend. (AT THIS THEY BOTH GO DOWN AND PICK UP THE BOOK 


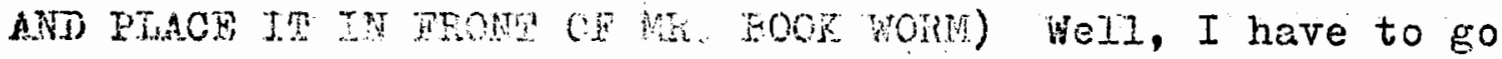

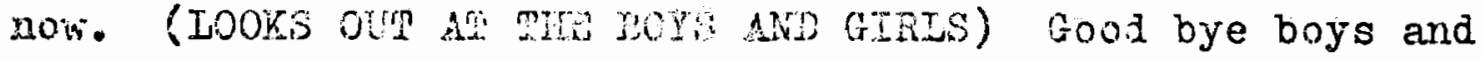
giris. (WITY WTS MISS FUEHANT GXITS)

Mr. Book Wom: Oh no!!! I can't read you a story yet; I don't lave my glasses on. Gome to think about it, where are my glassesi jo one of you cinilaren have my glasses? (IOOKS AROJND AT CAVRRA - DATSE) MO, I EUESS you couldn't. Mrs. Raccoon: Hi Mr. Fook Horm! that are you doing today? Mr. Book Worm: I an going to read the children a story. Miss Elephant came by End neiped me jn getting my book for the book had fallen way down there.

Mrs. Raccoon: Way dom tinere? (LOOKS IN DISHAY) My goodness, it's a good thing Niss Elephant came along and gave you some hel.p. Now you can read the story to the boys and giris.

Mr. Book Worm: I wish I could but I've misplaced my glasses - and I can't read without them.

Mrs. Raccoon: (IOOKS AROUHD FOR THE GLASSES) there they are. They must have fallen when your book fell. (PROCEEDS TO RETRIEVE GIASSES)

Mr. Book Worm: Oh thank you for your help. Can you stay and listen to the story? 
Beseroon: $I$ wish $I$ could, but I't looking for a new Jweling.

H. Boot Worn: A dweling? What is a dwelling?

Mrs. Recoon: A dwelling is a place where one lives. I'm inoking for a new home.

Mr. Book Worm: I whderstand. A dwelling is a home and a home is a dwelling. I bet each one of these boys and girls lives in a dwelling.

Mrs. Raccoon: Sure they do! The house they live in is their dwelling.

Mr. Book vorm: Our story today just happens to be about Chippy who is looking for a new place to live.

Mrs. Raccoon: You mean Chippy is locking for a new dwelling just like I ann?

Mr. Book Worm: Yes, and if you stay aid listen to the story, maybe you'll fina $\equiv$ new dwelling too.

Mrs. Raccogn: Could you wait to read the story until tomorrow? I promised to help Mr. Squirrel look for acorns to eat and I must be going.

Mr. Book Worm: OK Virs. Raccoon, I'll wait to read the story to you and the boys and girls until tomorrow. Sorry boys and girls, blit we have to help Mrs. Raccoon find a new 
dwoling - we he so he he rho a now rouse to live in.

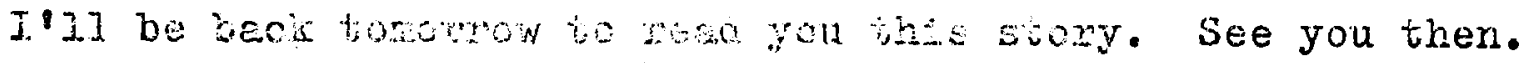
Good bys boys ano Einda.

\section{Second Days Pregentation}

Mr. Book Worx: Hi boys and girls, I'm back with your story. If you recall, Mrs. Raveocri je looking for a new place to live - a new dwelling.

Mrs. Paccoon: Yes, I think I need a cinange. I need a new aveling to live in.

Mr. Book Worm: Ilicky fox you Mrs. Raccoon, our story today is about a dog who is locing for a rew dweiling also. Are you ready boys and gixis for our story? Oh kay! (OK) our story begins like this...

Chippy (dog) ilved in an old rur down dog house. His dwelling was so old Chippy was afraid to sleep in it for fear it would fall upon his head. One day Chippy said:

Chippy: I have livea in this run dow dwelling for a long time. I am going to nove today. I am goirg to find a new house to live in. It's time I had a new dwelling. (CHIPPY FUTS HIS ONIY POSSESSION IN HIS MOUTH, A BOINE, AND STARTS WALIING) I want to have a new dwelling on a farm. I wiIl find a farm and I will live there. (PICKS UR BONA AND PROCEEDS TO SEARCH TOR A IJHW HOWE. MLETS MR. BIRD) 
Eird: Helio Chippy, Where ayo yom sotig?

Chipny: (DROPS BONF) i. gra Looring for a rew home. A new dwelling on a farm. Yes, I want to live on a farm. (PUTS BONE BACK IN MOJME; PROYSEDS TO SEAROA

Bird: Good luck, I hope you find a nice home. (EXIXS OFF STAGE)

Chippy: (STIII LOOHING - RUNS THTO CATERPILIJAR)

Caterpillar: Where are you going?

Chippy: (JAYS DOWN BONE) I am looking for a new home to live in. I want my new dwelling to be on a farm.

Caterpillar: My dwelling isn't on a farm but you sure are welcome to live with me. I live in that big house over. there. (LOOKS IN DIRECPION OF HOUSE - SIDE OF STAGE)

Chippy: Thank you, but I want to live in a ajog house on a farm. (PUTS BONE BACK IN MOUTH AND STAPTS DOHN THY ROAD AGAIN. MEEISS MR. FROG)

Frog: Hi Chippy! Where are you going? Ribbit, Ribbit

Chippy: (PUTS DOWN BONE) I am looking for a new dwelling, Mr. Frog; a big dog house on a farm.

Frog: Chippy, you could make your new dwelling here with we in the pond. 


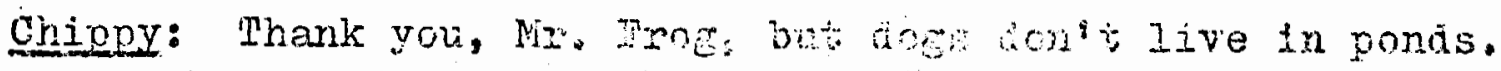

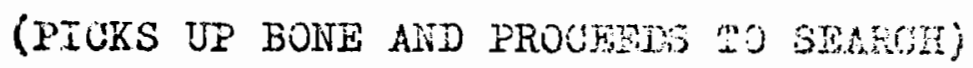

Mr. Book Woyn: Gee boys and gis?s, Wh chippy evex find a new home? Will his new diwelling be an a fams We will have to continue our story tolnorrow. Good bye boys and girls.

\section{Third Day's Presentation}

Mr. Book Worm: Hi! My name is Mr. Bcok Worm and I'm back to finish our story about Chippy the dog. Chippy, you. remember, is looking for a new dog house to Iive in. His old dwelling was so run down he was afraid to live in it any more. Do you still remenben what dwelling means? (PAUSE) Right - a place to live - a house - for you boys and girls your dwelling is your home - for Chippy his dwelling will be a new dog house. Now back to our story.

Chippy: (WITH BONE IN MOUTH HE WALLKS ACROSS SIAGE. PUTS BONE DOWN AND SAYS) I have been looking for a new home to live in. I want a dwelling on a farru with lots of animals to play with, but I have not been able to find a new dwelling. Miss Caterpillar said I could live with her but her dwelling was too smaIl and Mr. Frog said I could live with nim but his dweliing is in a pond of water and dogs don't live in water. Will I never find a new house on a farm? (PICKS UP BONE - CONTINUES TO JOOK FOR A DWELLIITG. STOPS 
kto ons Tohn 3oive) on look: Could that be? on yes it is. "Lerm. Cr boy, a fanm! This is where I will live. Where Le a new dos house waiting for me to move into it. What a twelling this will be. (WALKS UF TO DOG HOUSE; LOOKS IN)

Royen: Hey! What are you doing?

Qhjep: Grip! Hi Rover. I just spotted this nice new emoty dog house. It will nake a fire new dwelling for me.

Eover: Wait a mirute Chippy. This is my dwelling. I live here.

Chipp: This is your incise?

Roter: Yos to sure is my hore.

Chippy: (UOOKS OUT AT CAMERA) I thought I had found a new dwelling, but tinis dwelling is Rover's home. Oh what can I do? I have no place to live. (STARTS CRYING)

Rover: Piease don't ery. I'll nake a deal with you. If you help me with the chores here on the farm I will let you move in with me. Is that a deal?

Chippy: Oh, yes. I will help you. I will help you with all of your work. (J,OOKS OUT AT CAMERA) Oh, boys and girls, I have a new place to live; dweling on a farm.

Mr. Book Worm: Well, boys and girls that is our story. Aren't you glad Chippy found a new dwelling? $I$ sure am - 
and boys and giris we leamed a row wh tojay dweilins. Remember, a dwelling is a place to itye - like a house. I remember what "dwelling" means by streing a litile tuse. (SING TO IHE TUNE OF "THE PARMER IN THE DRII")
A place to live is a dwelling,
a place to live is a dwelling,
hi ho the dairy oh, a place to live is a dweling.

Everybody now!
A place to lite is a dwelling,
a place to live is a dwelling,
hi ho the dairy oh, a place to live is a dwelling.

Very good boys and girls. You know what a dwelling js now. Well I have to go now. Be good. Bye bye. 
APFENDIX B

VIDEO TAPI IUSSON PRESENRING THE CONCEPT

OF "ASSISTANCE"

\section{Iinst Day's Presentation}

Mr. Book Worm: Hi bojs anỏ girls. My name is Mr. Book worm. I'm called Mr. Book Worm because I like to read. I read everything. Today I'm going to read you a story. (LOOXS ARONND TOR BOCK) Ch my, where is my book? I just hao jit right here. (HOOKS AROUHD - SPOTS IT BACK STAGE) Miere it is?! It must have fallen down thare when I wasn't. looking. I'll reed some assistance to get the book. Who can I get to belp me? Is there no one here to help? (IOOKS AROUND - CAIT FIND ANYONE TO HELP - STARTS TO CRY) I wanted so very much to read you a story today but I can"t pick anytring up as big as a book, for I have no hands. (CRIES MORE)

Mr. Elephant: Hi, Mr. Bock Worm!

Mr. Book Worm: On gee Mr. Elephant, wolld you give we some assistance in getting my book?

Mr. Elephant: Sure I will! I will give you some - I will give you some - Now, what was that word? 


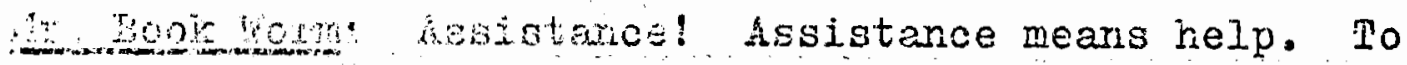
hap soneche its to give assistance. Iike when you need teip dotne the bishes - that's needing assistance.

Mr. Plephart: But - but, I dor't do dishes!!! - that's people's work.

Mr. Book Worm: Weil then, when you planted your garden last year you had help from your family to plant the seeds, that's assitgtenee.

Mr. Flephant: Oh! Assistance, ther, means to help do sornetining. Right?

No. Pock form: Right!! Now will you give me some asststance and pick up my book for me so I can read a story to these wonderfui boys and girls?

Mr. Eledhant: You bet I'II heIp you!! (AT THIS THE BOOK IS PLACED IN GRONT OF MR. BOOK WORM) Well, I have to go now. . Good bye bcys and girls. (MR. ELEPHANT EXITS)

Mr. Eook Worm: Oh no!! I can't read you a story yet, I don't have my giasses on. Come to think about it, where axe my glasses? Do one of you chlldren have my glasses? (JOOKS AROUND AT CAIMERA) No, I guess you couldn't.

Miss Raccoon: Hi Mr. Book Worm. What are you doing today? 


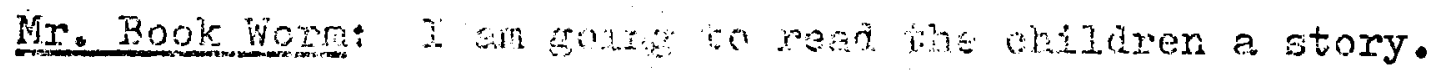
Mr. Elephat aem by and rave ne nssubared ix getting my book, for the book hod foblen was dow thare. (PoIN's To WHERE THS BOOK WDS;

Miss Raccoon: Way down bieres (WOOKS IXI DTSMAY) MY goodness, it's a good thtag Nir. Mluphent caine along and gave you some help. Now you can read the story to the boys and girls.

Mr. Book Woxm: I wish $T$ couid but I've misplaced mJ glasses and I can:ti rear whout them,

Miss Raccocn: I will help you find them. I always like to give assistance to my frienda. (THEY EORH BEGTN TO LOOK) Mr. Rabit once needed by asistance to build a new home for him and his femily, so I was wore trian glad to help. I bet you boys and giris give assistance to your fanily by helping dry the dishes, or helping to clean your room, or maybe even by ho]ping to take out the garbage, Am I right boys and girjs? (PAUSE) I sure hope so. (GOITTINUES to LOOK FOR GLASSES)

Mr. Book Worm: I found my glasses. Miss Raccoon will you give me some asaistance?

Miss Raccoon: (THEY ROTH DUSH GLASSES UP NEAR BOOK; AND BOOK WORM, WITH HELP, PUTS THEM ON) There you are Mr. Book Worm. Now you can read the story to the boys and girls. (EXITS OFF STAGE) 


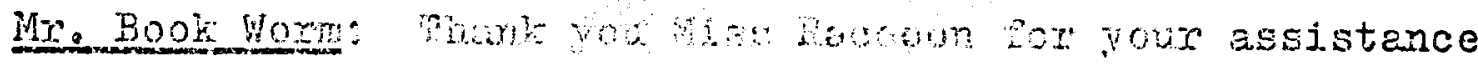

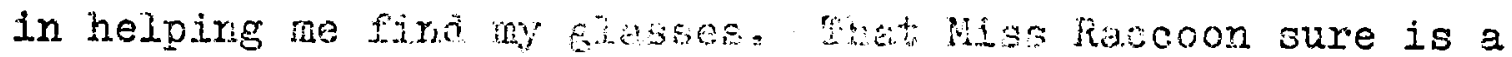
good friend. Iets sec row, whese wow we? oh yes, the

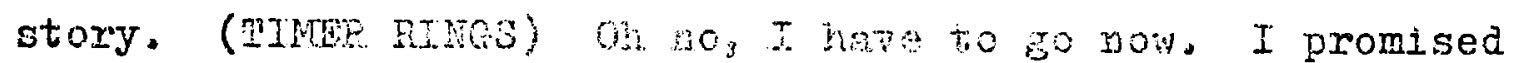
my mother I wovld sive her soire assistonco in helping her to babysit my iftice brother. Jon't be sad for I will be back tomorrow to reac you this wonderpul story. Good bye boys and girls.

\section{Jecoud Dey $y^{2}$ Presentation}

Mr. Book Wome Hi boys are giris. I'm beck with that story I promised you. Aro you ready? (FAUSES TOR REPIY) A]right! The story is anout a dog runcd chippy. (LOOKS AT BOOK AND BDGINS TO KiAD) ChIppy had the hiccups. He wanted to eat but could rot. The hiccups got in his way.

Mrs. Caterpilian: You sound Immy. (EEGINS TO LAUGH)

Chipoy: Hiccups are not finny. How can I make them go away? Can you give ine some assiatance by telling me how to make then go away?

Mirs. Caterpiliar: Mother had hiccups, She ran around and around and laughed.

Chippy: (AT THIS CHIPPI RUNS AROUND AND AROUND AND IWAUGHS AND LAUGHS - STOPS - IICCUPS) That wasn't much assistance: I atill have the hiccups!! 
Mas. Gaterpillar: Well, let me thirk - . M yos. Iajog had hiccups. He stood on his head. If you an bo thet th inay help.

GhingY: (STANDS ON HEAD - SZANDS UPRIGHT - HICOUPS) I still have the ficcups. This is bad! (VAIJS ORE ACROSS SHACE, WEN HE COMES BACK HE REELS GREEN DRAGOH)

Green Dragon: I hear you have the hiccupa. Hochpis are vesy very bad if you do not do something for then.

Chippy: Mr. Dragon, I did what Mrs. Caterpiliar wanted ne to do. I ran around and around and I laughed ard laughed. I stood on my head, too, but my hiccups ald not ge away. MIs. Caterpillar didn't give me much assistancs at all!!!

Green Dragon: You stood on your head? (BEGINS TO LAUGH) Iricks like that are no good. Do you know what I do if I have the hiccups?

Chipoy: No, Mr. Dragon. What ao you do for hjccups?

Green Dragon: I breathe fire!! When I breathe fire I can get rid of my hicoups every time.

Chippy: You're no assistance either!! You know a dog can: $t$ breathe fire, only dragons can!!

Green Dragon: It's too bad you're not a dragon; breathing fire gets rid of hiccups everytine. Sorry I wasn't much assistance. 


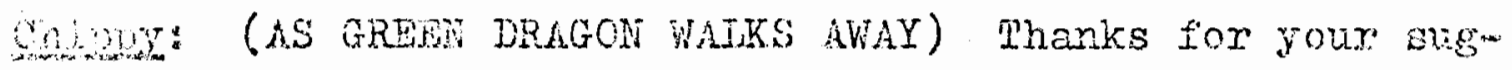
agstion aryway, Nis. Dregon. (HICCUPS)

2. GGLE COLES ON STAGE

Zffrele: II ccups? You could do something for them if you wanted to.

Chiopy: I djd, zigele. Mrs. Caterpiliar and Mr. Dragon tried to give me assistance. I laughed and I ran around, I stood on my head, Mr. Dragon even wanted me to breathe tire. whe hiocups never did go away. (HICCUPS)

Zigele: Not very much assistance at all!! Count to three ard then put your head irto the sand. My hiocuns go away wher I do that.

Chpog: One, liwo, three. (PUTS FEAD INTO SAND - THEN Hi STANDS UP TO SEI IF HE STIL, HAS THE HICCUPS) Hiccup!!!!! Ziggle, sand will never make my hiccups go away. This will never help. (WAJKS AWAY)

AS OHTPPY WALKS ACROSS THE STAGE HE MEETS NISS RABBIT

Chippy: Miss Rabijt, I need some help. What do you do for hicclips? I Ialughed and I ran around. I stood on my head. Mr. Dragon even wanted me to breathe fire. I put my head in sand. Ziggle does that for hiccups. When I stood up I still had thern. No one ras been of assistance in helping my hiccups go away. 


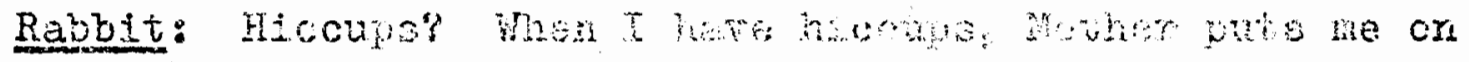
her back and jrims around.

Chipp: Ny mother san't jume itte row nother.

Rabbit: Hop on my back and I will jump until your biccups

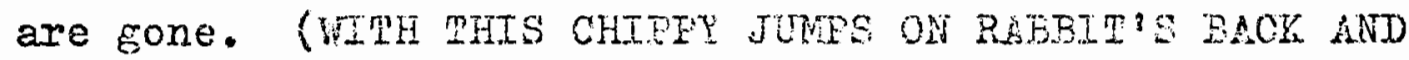
RABBIT JUMPS VIGOROUSII;

Chippy: Whoa, Whoa!!!! What a ride. Hiccup! On Miss Rabbit, I stili naye the hiccups, Miss Rabbt, this will never do. (CHPPY GOES ON HES WH. REBDIT EXTS)

Qhippy: Can't aryone give ine some gsaistance in getting rid of my hiccups? I ran around and lenghed. I gtood on my head. I put my head in the sand. Miss Rabbit jumped with me or her back and. I still have the hiccups. No one has been able to help me. Ihis will never, never do!!!!!! (SITS DOWN AND BEGINS TO CRY)

Mr. Book Worm: Will Chippy ever get rid of the hiccups, boys and giris? Tomarrow we will find out the answer. Between now and tomorrow mavbe you could give jour nother assistance drying the dishes. I'm sure she would like that. Bye-bye.

Third Day's Presentation

Mr. Book Worm: As you can recall, Chippy has the hiccups and can't seem to get rid of them. He has askej help from 
Hes, Caterpillax, Mr. Green Tragon, Ziggle, and Miss gabbit, but no ore has given him any valuable assistance in getitrig wia of his hiccups.

Chipgy: (CRYTNG, UP CONES ROVER)

Rover: Chippy, I rave the hiccups. (HICCUF!) Do you know what to do for them?

Chippy: I know what not to do. Do not mun around and around and laugh. Do not starid on your head. Do not stick your nead in the sand and do not ride around on Miss Rabbjt's back. No one has given me any assistance in getting rjo of my hiccups. (SITS DOWN AND BEGINS TO CRY)

Rover: What can we do?

Clipoy: Ask those pigs over there in the water. (IIGS ARE OFF STAGE. ROVER LOOKS IN THE DIRECIION OF PIGS)

Roten: Chippy and I have the hiccups. What do you do for hiccups?

Pigs: We never have hiccups, but Mother had them one day.

Rover: What did she do?

Pigs: She sat on jee.

Rover: Ice!! Ice!! Where can we find ice on a hot day like this? 
Pigs: We do not know.

Rover: (CRYIIG) Your suggestion has not been jnuch assistance for my hiccups. (IOOKS BACK AT CHIPrY)

Chippy: What do the pigs do? Hiccup!

Rover: They said that Mrs. Pig sat on ice for her hiccups. The pigs were no help.

Chippy: (CRYING) That will never do! No one could find ice on a hot day. I will get a drink of water and then I will go to sleep.

Rover: I will go home.

Mix. Book Worm: Chippy went to sleep and had a very good sleep. When he awoke he got up and stood very still. He wanted to see if the hiccups had gone away. He could not hear a sound. He jumped around and around. Then he stood very still. The hlccups were gone!!!!!! (PAUSE) But

Chippy never did find out what makes hiccups go away. The end. That was a real good story wasn't it boys and girls? We learned a new word from our story; assistance. Class, do you remember what assistance means? Yes, assistance means to help.

Zab: I remember what assistance means by singing a little tune.

(SING TO TUNE OF THE F'ARMER IN THE DELL) 
diswistape meanis to help someone, assistance wown to heip somoone,

he 70 bhe dajry on, assistance means to help someone.

Now Ie: :s sing the sone together. Ready go.

Assj. stance means to help someone, assistance means to help someone, hit ho the datry on, assistance means to help someone.

Veny good. Therk you for the assistance you gave me in singing this song.

ive Eook rom: Mhanir you zab, and. thank you boys and gixls for being such a good avdience. Bye-bye. 